\title{
Recent advances in understanding and combatting Neisseria gonorrhoeae: a genomic perspective
}

\author{
Odile B. Harrison (iD ${ }^{1 *} \quad$ Martin C.J. Maiden
}

${ }^{1}$ Department of Zoology, University of Oxford, The Peter Medawar Building, Oxford, UK

\begin{abstract}
The sexually transmitted infection (STI) gonorrhoea remains a major global public health concern. The World Health Organization (WHO) estimates that 87 million new cases in individuals who were 15 to 49 years of age occurred in 2016. The growing number of gonorrhoea cases is concerning given the rise in gonococci developing antimicrobial resistance (AMR). Therefore, a global action plan is needed to facilitate surveillance. Indeed, the WHO has made surveillance leading to the elimination of STIs (including gonorrhoea) a global health priority. The availability of whole genome sequence data offers new opportunities to combat gonorrhoea. This can be through (i) enhanced surveillance of the global prevalence of AMR, (ii) improved understanding of the population biology of the gonococcus, and (iii) opportunities to mine sequence data in the search for vaccine candidates. Here, we review the current status in Neisseria gonorrhoeae genomics. In particular, we explore how genomics continues to advance our understanding of this complex pathogen.
\end{abstract}

\section{Keywords}

gonorrhoea, genomics, MLST, Antimicrobial resistance

\section{Peer Review}

The peer reviewers who approve this article are:

1. Ann E Jerse, Uniformed Services University of the Health Sciences, Bethesda, MD, USA Competing interests: No competing interests were disclosed.

2. Jo-Anne R Dillon, Department of Biochemistry, Microbiology and Immunology, Vaccine and Infectious Disease Organization-International Vaccine Centre, University of Saskatchewan, Saskatoon, Saskatchewan, Canada Competing interests: No competing interests were disclosed. 
*Corresponding author: Odile B. Harrison (odile.harrison@zoo.ox.ac.uk)

Competing interests: The authors declare that they have no competing interests.

Grant information: OBH and MCJM are funded by the Wellcome trust (grants 218205/Z/19/Z and 214374/Z/18/Z).

The funders had no role in study design, data collection and analysis, decision to publish, or preparation of the manuscript.

Copyright: (C) 2021 Harrison OB et al. This is an open access article distributed under the terms of the Creative Commons Attribution License, which permits unrestricted use, distribution, and reproduction in any medium, provided the original work is properly cited.

How to cite this article: Harrison $\mathrm{OB}$ and Maiden MCJ. Recent advances in understanding and combatting Neisseria gonorrhoeae: a genomic perspective. Faculty Reviews 2021 10:(65) https://doi.org/10.12703/r/10-65

Published: 27 Aug 2021, Faculty Reviews 10:(65) https://doi.org/10.12703/r/10-65 


\section{Introduction}

Neisseria gonorrhoeae, the gonococcus, is an obligate human pathogen that causes the sexually transmitted infection gonorrhoea $^{1}$. Gonococcal infection often results in severe complications, ranging from disseminated infection to salpingitis or pelvic inflammatory disease, and gonococcal infections are found to be asymptomatic in over $50 \%$ of women and associated with a significant cause of infertility ${ }^{2}$. Therefore, prompt diagnosis and treatment are essential for a positive clinical outcome. However, the gonococcus has developed resistance against all available classes of antimicrobials and options for the effective treatment of this infection are becoming increasingly limited ${ }^{2,3}$. This is particularly concerning as gonorrhoea, after Chlamydia trachomatis, is the second most prevalent sexually transmitted infection and is globally associated with high levels of morbidity and economic cost ${ }^{4}$.

Infections are diagnosed by microbiological culture (with Gram stain in men with urethritis) or nucleic acid amplification tests. In settings with limited laboratory capacity, diagnosis is often based on clinical symptoms alone, followed by syndromic management. This commonly includes the use of doxycycline, an antibiotic that targets both $N$. gonorrhoeae and C. trachomatis, which present with similar clinical symptoms ${ }^{5}$. However, treatment has become complicated by the rapidly changing antimicrobial susceptibility patterns of N. gonorrhoeae, raising concerns about the development of untreatable gonorrhoea. Internationally, the prevalence of gonococci resistant to most antimicrobials recommended for treatment is high. For example, the recent occurrence of failures to treat gonorrhoea with the extended-spectrum cephalosporins (ESCs) cefixime and ceftriaxone and, the emergence of gonococci exhibiting high-level resistance to all other available therapeutic antimicrobials ${ }^{6-8}$, have caused great concern and highlight the need for a targeted approach to limit the spread of infection and prevent transmission globally.

Understanding the causative agents of disease is paramount to curing or preventing disease, and the availability of whole genome sequence (WGS) data offers novel opportunities to do this. In particular, a large amount of $N$. gonorrhoeae WGS data have become available, allowing an increasingly forensic examination of this bacterium. The knowledge gained from these analyses strengthens our capacity to detect antimicrobial resistance (AMR) while improving our understanding of the resistance phenotype and how it evolves. This knowledge also allows the population biology of the gonococcus to be resolved, facilitating global surveillance. Finally, WGS data provide opportunities for vaccine development through the characterisation of antigenic variability. Here, we review progress made in the field of gonococcal genomics, examining how WGS data have increased our knowledge of this pathogen. In particular, we focus on advances made in the detection of AMR, the genetic determinants conferring this phenotype, and the tools developed to identify AMR. We assess progress made in understanding the population biology of this pathogen and discuss the current status in vaccine development and how WGS can support this activity. To conclude, we review the challenges that remain and discuss the approaches needed to overcome them.

\section{Antimicrobial resistance}

In the absence of vaccines, antimicrobial therapy is critical to cure infection and limit its spread ${ }^{9}$. The effectiveness of antibiotics to treat gonorrhoea is becoming limited by the global emergence and spread of gonococci resistant to antimicrobials, combined with increasing rates of gonorrhoea. The total number of confirmed cases reported in 2018 in 28 European Union/European Economic Area (EU/EEA) member states was 100,673 (with an overall crude notification rate of 26.42 per 100,000 population), representing a $12 \%$ increase in the total number of reported cases compared with 2017 10,11 . In the UK alone, 61,775 confirmed cases were reported in 2018, representing a $26 \%$ increase compared with $2017^{10}$. In the US and its territories, 556,413 cases of gonorrhoea were reported in 2017, representing a rate of 168.9 cases per 100,000 population and a $19 \%$ increase compared with $2016^{12}$. In Australia, the number of confirmed cases rose from 23,875 in 2016 to 28,364 in 2017 with a rate of 118 per 100,000 population $^{13}$. This was associated with a $63 \%$ increase in notification rates between 2012 and 2016. In China, 133,156 confirmed cases were reported in 2018, representing a rate of 10.06 cases per 100,000 population ${ }^{14}$. Similarly, a rate of 88.6 cases per 100,000 population was identified in 2015 in Japan $^{10,15}$. These data are consistent with a global trend of increasing rates of gonorrhoea. However, there are differences in the reporting of incidence and prevalence data among countries, even where effective surveillance systems are in place. In addition, different jurisdictions have their own surveillance methodologies and diagnostic tests such that global estimates have to be interpreted with caution ${ }^{3}$. So it is challenging to assess effectively global rates of gonorrhoea prevalence.

This increasing trend in gonococcal prevalence is accompanied by global reports of gonococci exhibiting decreased susceptibility to several classes of antimicrobials ${ }^{2,16}$. The gonococcus employs multiple genetic mechanisms to overcome the effects of antimicrobial agents and is extremely adept in developing AMR (Figure 1). Most of the genetic determinants that confer AMR in $N$. gonorrhoeae are chromosomally encoded (Table 1), with plasmid-mediated AMR associated only with the blaTEM gene, which confers high-level resistance to penicillin $^{17-19}$, and the tetM gene associated with resistance to tetracycline ${ }^{20,21}$ (Table 1). Resistance to fluoroquinolones is conferred through the presence of non-synonymous mutations in DNA gyrase, gyrA, or the topoisomerase IV gene, parC, and amino acid mutations in both GyrA and ParC result in higher levels of resistance to fluoroquinolones ${ }^{22,23}$.

An increasing level of resistance or reduced susceptibility to beta-lactams, including penicillin and third-generation cephalosporins, is often the result of combinations of mutations in several genetic determinants (Table 1). These include (i) the 


\section{Neisseria gonorrhoeae}

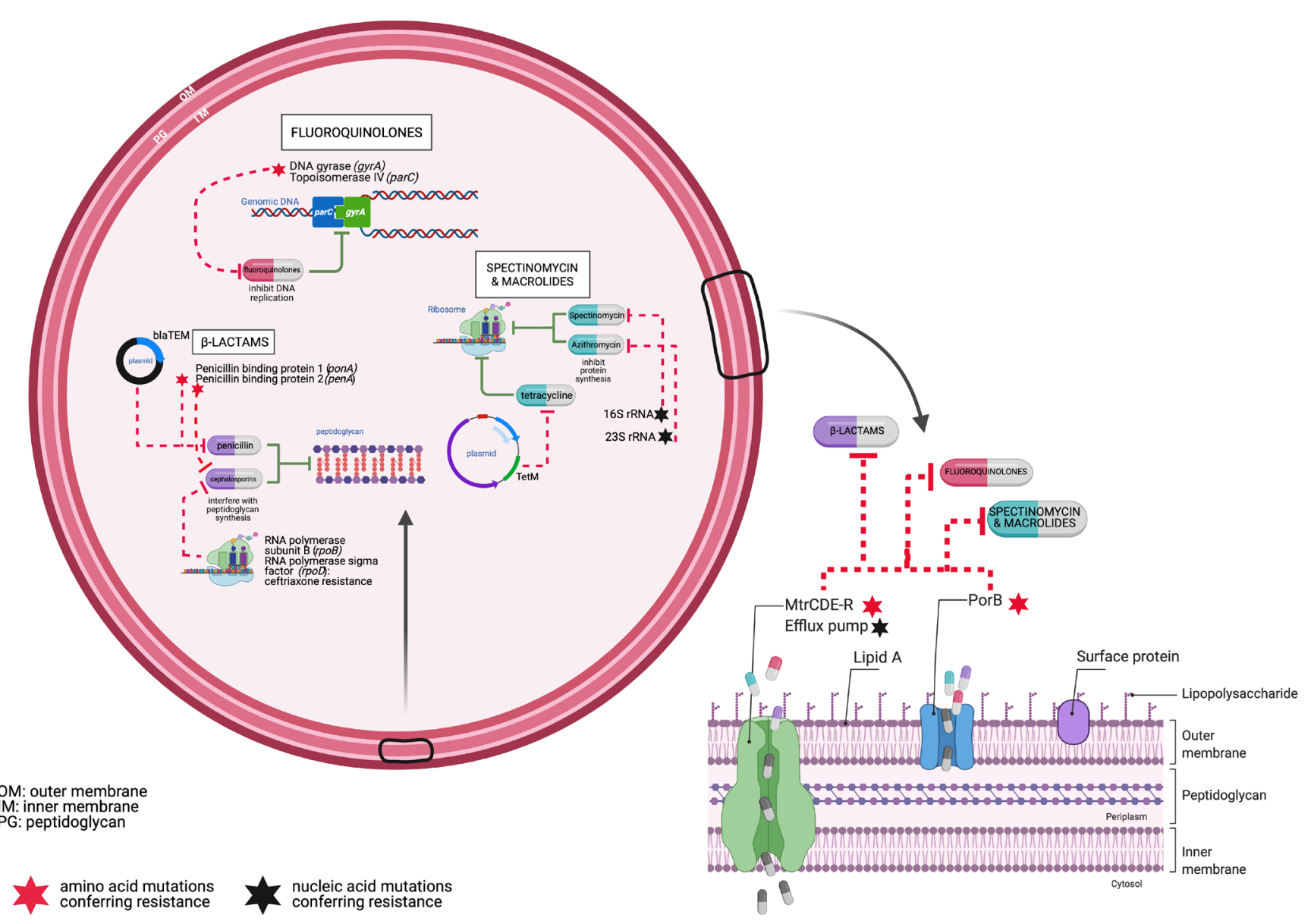

Figure 1. Antimicrobial resistance mechanisms in the gonococcus. Schematic figure of a gonococcus depicting chromosomally and plasmid-mediated resistance determinants. Multiple antibiotics target the gonococcus against which the bacterium has in turn developed resistance. This includes (i) fluoroquinolones (e.g., ciprofloxacin), which inhibit the activity of topoisomerases involved in DNA replication. Resistance to fluoroquinolones is conferred by non-synonymous mutations in the topoisomerase-encoding genes gyrA and par $C^{24,25}$; (ii) beta-lactams target penicillin binding protein 1 (PBP1) and 2, which are required for peptidoglycan synthesis. Amino acid mutations in ponA and penA, which encode PBP1 and PBP2, respectively, confer resistance to beta-lactams ${ }^{26-28}$. Gonococci are increasingly developing reduced susceptibility to third-generation cephalosporins, including cefixime and ceftriaxone, with the presence of multiple genetic determinants required for this phenotype, including mosaic penA alleles ${ }^{29-31}$. More recently, mutations in $r p o B$ and $r p o D$ have been found to confer resistance to ceftriaxone only in the absence of mosaic penA alleles ${ }^{32}$; (iii) spectinomycin and macrolides, including azithromycin, bind to ribosomes inhibiting protein synthesis. Mutations in the 16S and 23S rRNA confer resistance to spectinomycin and azithromycin, respectively ${ }^{33-35}$. Additional chromosomally mediated resistance determinants include amino acid mutations in loop 3 of the outer membrane porin PorB, which reduces permeability, thereby inhibiting the influx of antibiotics through the porin channe ${ }^{36}$. Mutations in efflux pump genes $m \operatorname{trRCDE}$, particularly in the promoter of $m t r R$, which encodes the MtrR repressor protein, lead to overexpression and increased activity of the efflux pump complex, conferring resistance ${ }^{37-39}$. Mosaic $m t r D$ genes have been found to confer resistance to azithromycin ${ }^{40}$. Plasmidencoded resistance includes the plasmid-encoded TEM-1 penicillinase $\left(\right.$ bla $_{T E M-1}$ ), which inactivates the beta-lactam ring of penicillin and the conjugative plasmid harbouring the tetM gene ${ }^{19,21}$. IM, inner membrane; OM, outer membrane; PG, peptidoglycan. Red stars indicate non-synonymous nucleotide mutations resulting in amino acid mutations; black stars nucleic acid mutations in the rRNA nucleotide sequences. Green lines indicate antibiotic targets; dashed red lines depict resistance mechanisms. Figure created using BioRender.

presence of mosaic penA genes encoding penicillin binding protein 2, genetic fragments of which often are acquired through horizontal gene transfer (HGT) from commensal Neisseria species $^{41-43}$; (ii) non-synonymous mutations in the ponA gene, which encodes penicillin binding protein $1^{26,27}$; (iii) the presence of mutations in the $m t r R$ repressor gene or its promotor sequence, resulting in overexpression of the MtrCDE efflux pump system and secretion of antimicrobial agents ${ }^{37,38}$; and 


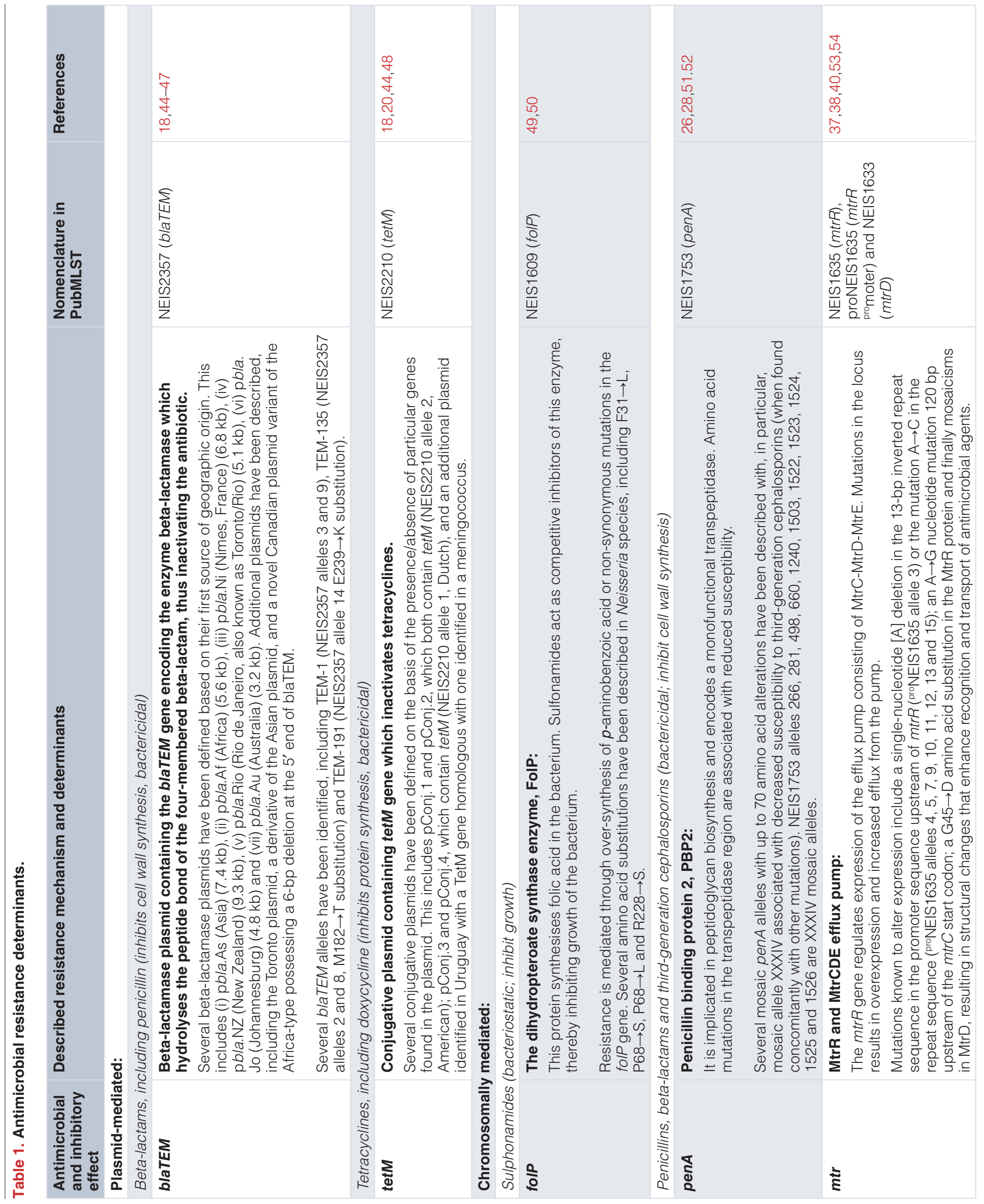




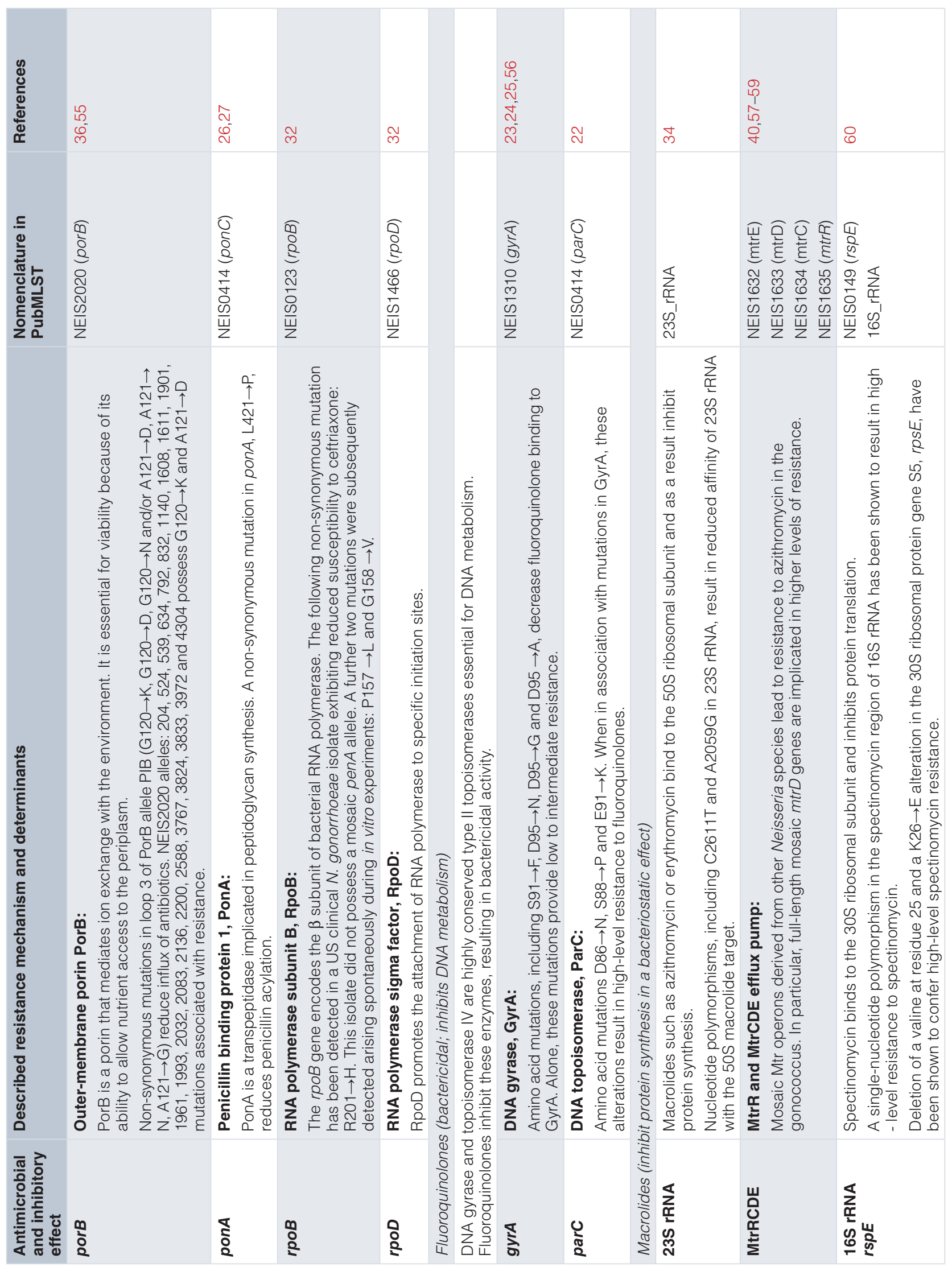


(iv) mutations of the outer membrane channel porin PorB variant PIB, resulting in a decreased influx of penicillin, through reduced permeability of the porin ${ }^{26,36}$. In addition, mutations in $r p o B$, encoding RNA polymerase subunit $\mathrm{B}$, and rpoD, encoding the RNA polymerase sigma factor, have been identified (Table 1) ${ }^{32}$. These mutations, which cause large-scale transcriptional changes, including an increase in ponA expression, were detected in clinical isolates which lacked penA mosaic alleles and yet exhibited reduced susceptibility specifically towards ceftriaxone only. The number of potential mutations implicated in conferring resistance to beta-lactams highlights the genetic diversity and complexity of this genotype and the possibility that other as-yet-unknown mutations are present or indeed will arise in the future.

The macrolides, azithromycin and erythromycin inhibit protein synthesis by binding to the 23S rRNA component of the 50S ribosome. Mutations in 23S rRNA can lead to resistance and include a $\mathrm{C} 2611 \mathrm{~T}$ change resulting in low levels of resistance or an A2059G mutation leading to increased resistance ${ }^{61,62}$. Levels of resistance are also dependent on how many of the four copies of $23 \mathrm{~S}$ RNA contain either mutation such that, for example, A2059G mutations, if present in three or all four of the 23S rRNA alleles, result in high-level azithromycin resistance ${ }^{6,62}$. Mosaic $m t r$ alleles are also associated with conferring resistance to azithromycin ${ }^{40,57-59}$. The mechanism of resistance is distinct from those associated with increased expression of the MtrCDE efflux pump and is due to the presence of mosaic $\mathrm{mtr}$ operons where, in particular, full-length mosaic $m t r D$ genes combined with a mosaic $m t r$ operon lead to much higher levels of resistance to azithromycin compared with isolates with mosaic $m t r$ operons alone. Such $m t r$ operons were found to result from interspecies HGT with other Neisseria species, including $N$. meningitidis and $N$. lactamica. Finally, resistance to spectinomycin is conferred through mutations in the $\operatorname{rps} E$ gene, which encodes the $\mathrm{S} 5$ ribosomal protein, and $\mathrm{T} 24 \mathrm{P}$ mutations that induce low levels of resistance ${ }^{63}$. A deletion of a valine residue at amino acid 25 and a K26E amino acid substitution have also been found to be associated with higher levels of resistance ${ }^{60}$. Resistance to spectinomycin can also occur through a C1192U nucleotide polymorphism in $16 \mathrm{~S}$ rRNA ${ }^{33}$.

In addition to the genetic mutations described above, all of which expand in response to antimicrobial exposure, selection for resistance in gonococci may occur as a consequence of indirect exposure through the consumption of antibiotics intended to treat another pathogen ${ }^{64}$. For example, differences in the consumption of fluoroquinolones across 24 EU/EEA countries correlated with ciprofloxacin resistance in gonococci ${ }^{65}$. Seasonal variations in antibiotic consumption have also been associated with fluctuations in numbers of gonococci exhibiting resistance to azithromycin, possibly a consequence of increased use of macrolide to treat respiratory infections ${ }^{66}$. Therefore, a driver in the development of AMR in the gonococcus may also result from the bystander effect, which may be more prevalent than anticipated, particularly since gonorrhoea infections are often asymptomatic.
To monitor resistance, gonococci are classified as either multidrug-resistant (MDR-GC) or extensively drug-resistant (XDR-GC): MDR-GC is defined as a gonococcus with decreased susceptibility to one currently recommended therapy (cephalosporin or azithromycin) plus resistance to at least two other antimicrobials, whereas XDR-GC is a gonococcus with decreased susceptibility to two currently recommended therapies (i.e., cephalosporin and azithromycin) plus resistance to at least two other antimicrobials ${ }^{67,68}$. Rapid detection of MDR-GC or XDR-GC is crucial to limit their spread, and advances made in genomics play an increasingly central role in assisting in this where this technology is available. For example, WGS studies identified an association between the mosaic XXXIV penA allele and reduced susceptibility to the ESC cefixime when found in conjunction with additional resistance factors ${ }^{29}$. Genomic epidemiology studies have also allowed transmission outbreaks of azithromycin-resistant gonococci to be tracked in England ${ }^{69}$, and further studies have elucidated transmission networks in men who have sex with men in Australia ${ }^{70}$. WGS studies identified mosaicisms in the $m t r D$ gene (a component of the mtrCDE efflux pump) that enhance the capacity of the protein to export antimicrobial agents ${ }^{40}$.

Genomic technologies therefore offer the tantalising prospect of enhancing surveillance of AMR with several bioinformatic tools developed to predict AMR from WGS data. These include (i) Antimicrobial Resistance Identification By Assembly (ARIBA), which identifies AMR genes and variants from paired sequencing reads through the use of a combined mapping/alignment and targeted local assembly approach ${ }^{71}$; (ii) the Pathogenwatch AMR prediction module, PAARSNP, which can be used through the Pathogenwatch portal and which uses resistance databases developed in-house ${ }^{72,73}$; and (iii) $\mathrm{ABRICATE}^{74}$. Performance of these in silico AMR prediction tools is dependent on the availability of accurate and curated AMR databases such as ResFinder ${ }^{75}$ and CARD $^{76}$ and those reviewed by Hendriksen et al. ${ }^{77}$. Concordance between phenotype and genotype is stronger for some genetic determinants than others. For example, ciprofloxacin resistance can be readily determined from sequence data, whereas predicting beta-lactam-resistant genotypes is more challenging, particularly as this is often an additive effect resulting from multiple mutations. As a result, several studies have encountered difficulties when using WGS to predict such AMR phenotypes $^{78,79}$.

Other approaches have employed multivariate linear regression models to identify genetic predictors of minimum inhibition concentrations (MICs). These models predict MICs for five gonorrhoea antimicrobials that exhibit different genetic mechanisms of resistance: cefixime, penicillin, azithromycin, ciprofloxacin and tetracycline ${ }^{80}$. More recently, a method called 'genomic neighbour typing', which allows the AMR phenotype of a bacterial sample to be predicted through the identification of its closest relatives in a database of genomes which have corresponding AMR metadata, has been described. This method was tested in both Streptococcus pneumoniae and $N$. gonorrhoeae datasets, and preliminary results indicate 
that this approach may work well for the pneumococcus given the greater sequence diversity observed in its core genome, which allows specific signature sequences to be more readily detected and matched to individual lineages. However, the lower diversity found in the gonococcal core genome results in the identification of multiple related neighbours which confounds obtained signals ${ }^{81}$.

An alternative approach for tracking AMR in the gonococcus is through the use of a multilocus sequence typing scheme, NG STAR (Neisseria gonorrhoeae sequence typing for antimicrobial resistance), which indexes variability found in nucleotide sequence fragments from seven genes associated with AMR (penA, mtrR, porB, ponA, gyrA, parC, and 23 rRNA) $)^{82}$. Using an online, publicly available database (https://ngstar. canada.ca), users can submit new alleles for curation, allowing variation in genes conferring resistance to be defined and tracked. New allelic profiles are assigned NG STAR sequence types (STs), which are associated with corresponding isolate records. Since its publication, this tool has been used in several international studies assessing AMR, thus providing a tool with which to track the worldwide dissemination of resistant clones. All described genes associated with AMR in the gonococcus, both chromosomally and plasmid-mediated, have also been defined in the pubMLST.org/neisseria database with mutations annotated in allelic variants ${ }^{83}$. This database includes the NG STAR, multi-locus sequence typing (MLST) and $N$. gonorrhoeae multi-antigen sequence typing (NG MAST v2.0) schemes $^{84}$. As a result, WGSs deposited in PubMLST are annotated in all of these schemes, allowing AMR to be evaluated in combination with conventional typing schemes and providing a publicly available resource for the analysis of gonococcal WGSs. Furthermore, WGSs can be directly queried for any of these schemes without the need for WGSs to be deposited. An additional publicly available tool, Gen2Epi, facilitates gonococcal WGS assembly followed by automatic retrieval of molecular epidemiological information, including NG STAR, MLST and NG MAST and AMR genotypes ${ }^{85}$.

\section{Gonococcal population genomics}

The study of genomics will play an increasingly important role in enhancing surveillance of AMR and in the development of molecular diagnostic tools for the detection of this phenotype. AMR emergence has to be studied alongside population structure and genome content since the dynamics of gonococcal population biology is complex and highly influenced by HGT, which results in diversification and reassortment of genetic variation over time ${ }^{86,87}$.

Several molecular typing tools have been developed to identify gonococcal isolates, including (i) MLST, which indexes the diversity found at seven housekeeping gene fragments, and (ii) the NG MAST scheme, where nucleotide sequence fragments of the outer membrane proteins PorB and TbpB are used to define NG MAST STs ${ }^{88,89}$. MLST is based on the characterisation of fragments from housekeeping genes under stabilising selection and remains the method of choice for typing many bacterial species, including Neisseria meningitidis, the meningococcus, for which MLST was first developed ${ }^{90}$. Meningococcal MLST STs provide a convenient means for tracking the epidemiology and population biology of this bacterium since STs can be grouped into coherent groups known as 'clonal complexes' (ccs) $)^{91}$. A number of these ccs, 'the hyperinvasive meningococci', are responsible for the majority of invasive disease cases worldwide and are stable over time and global spread ${ }^{91,92}$. The levels of linkage disequilibrium observed in meningococci result in the non-random association of MLST allelic profiles, producing discrete persistent meningococcal lineages, some of which exhibit an invasive phenotype ${ }^{93}$. Studies of the genetic diversity of gonococcal housekeeping genes have shown that, in addition to diversification arising from randomly distributed point mutations, these genes are frequently subject to $\mathrm{HGT}^{94,95}$. As a result, some gonococci, though possessing the same seven locus MLST STs, may have different ancestry in the majority of their loci and consequently MLST STs cannot be used to reliably evaluate gonococcal populations ${ }^{84,96}$. In addition, combinations of MLST alleles in gonococci are unlikely to be associated with transmission fitness or stabilising selection in contrast to the meningococcus ${ }^{94}$.

The high rate of HGT observed in the gonococcus led to the assumption that limited structure would be evident in its populations ${ }^{95}$. Genomic population studies have shown otherwise $^{96,97}$. Hierarchical Bayesian analyses (Bayesian Analysis of Population Structure, or BAPS) uses nucleotide polymorphism-based alignments to generate clusters of related isolates after accounting for HGT identified by tools such as Gubbins ${ }^{98,99}$. With this method, gonococcal genome data from several studies have been found to consist of between six and 12 BAPS clusters, some of which associated with AMR phenotypes $^{96,97,100}$. This is consistent with a semi-clonal population structure (i.e., one in which there is residual clonal signal in the population $)^{96,97,100,101}$. The presence of distinct gonococcal lineages was also evident in studies of the gonococcal core genome. For example, more than 1,600 genes were identified as 'core' in WGS data from over 4,000 gonococci: these genes have been defined in the PubMLST database (https://pubmlst.org/neisseria) and form part of the $N$. gonorrhoeae cgMLST version 1.0 scheme $^{84}$. Core genome STs are assigned for each isolate and, through single-linkage clustering and the use of increasing allelic difference thresholds, isolates can be grouped into related core genome groups (Figure 2). Use of this approach identified discrete clusters of gonococci, some of which persisted over time and associated with AMR genotypes ${ }^{84}$. Thus, analyses composed of higher numbers of genes, and therefore higher genome content, improve resolution and are required to investigate the gonococcal population and detect structure in this highly recombining species.

In the meningococcus, non-overlapping antigenic repertoires are found among different genotypes, resulting in the circulation of distinct meningococcal lineages, the prevalence of 

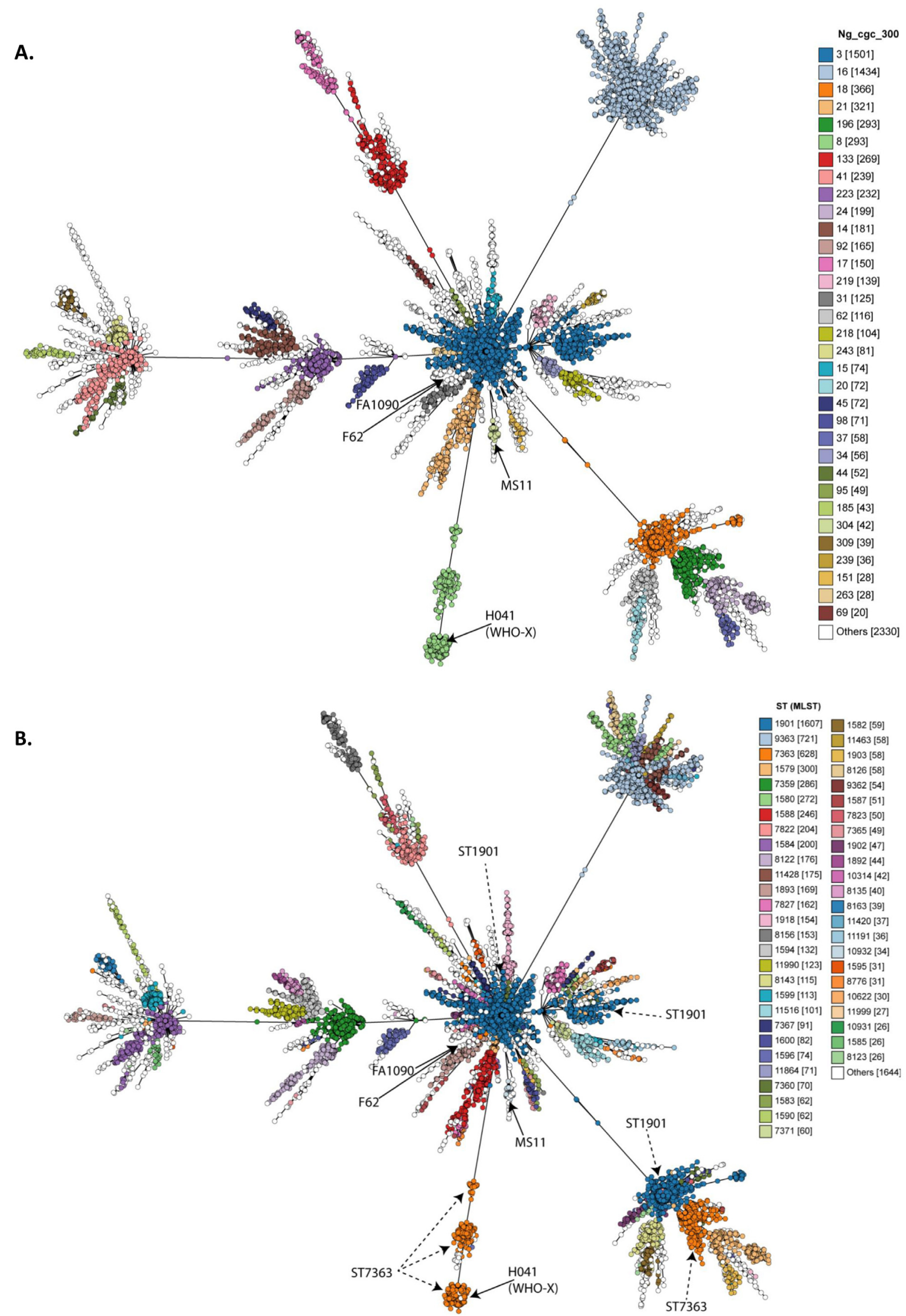


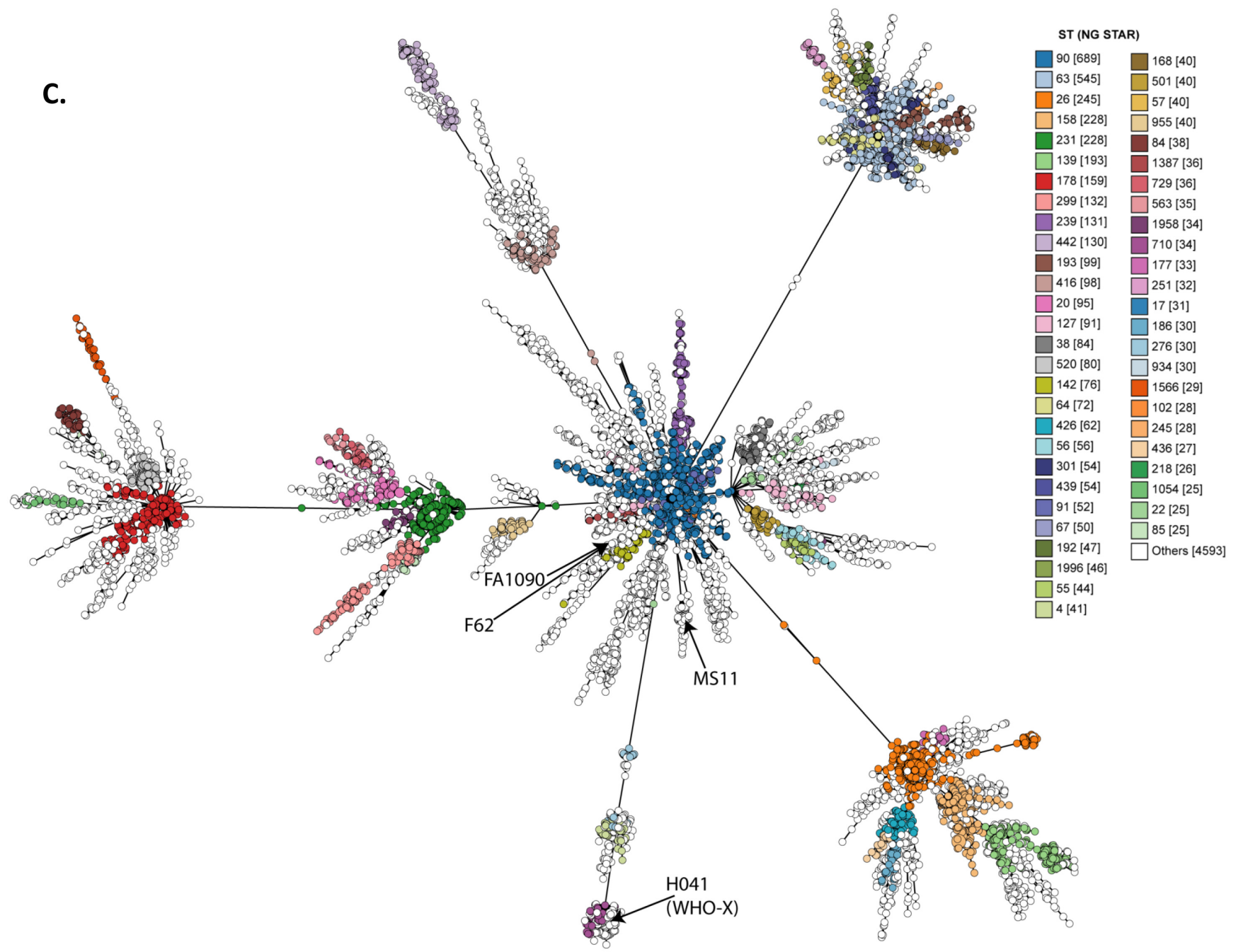




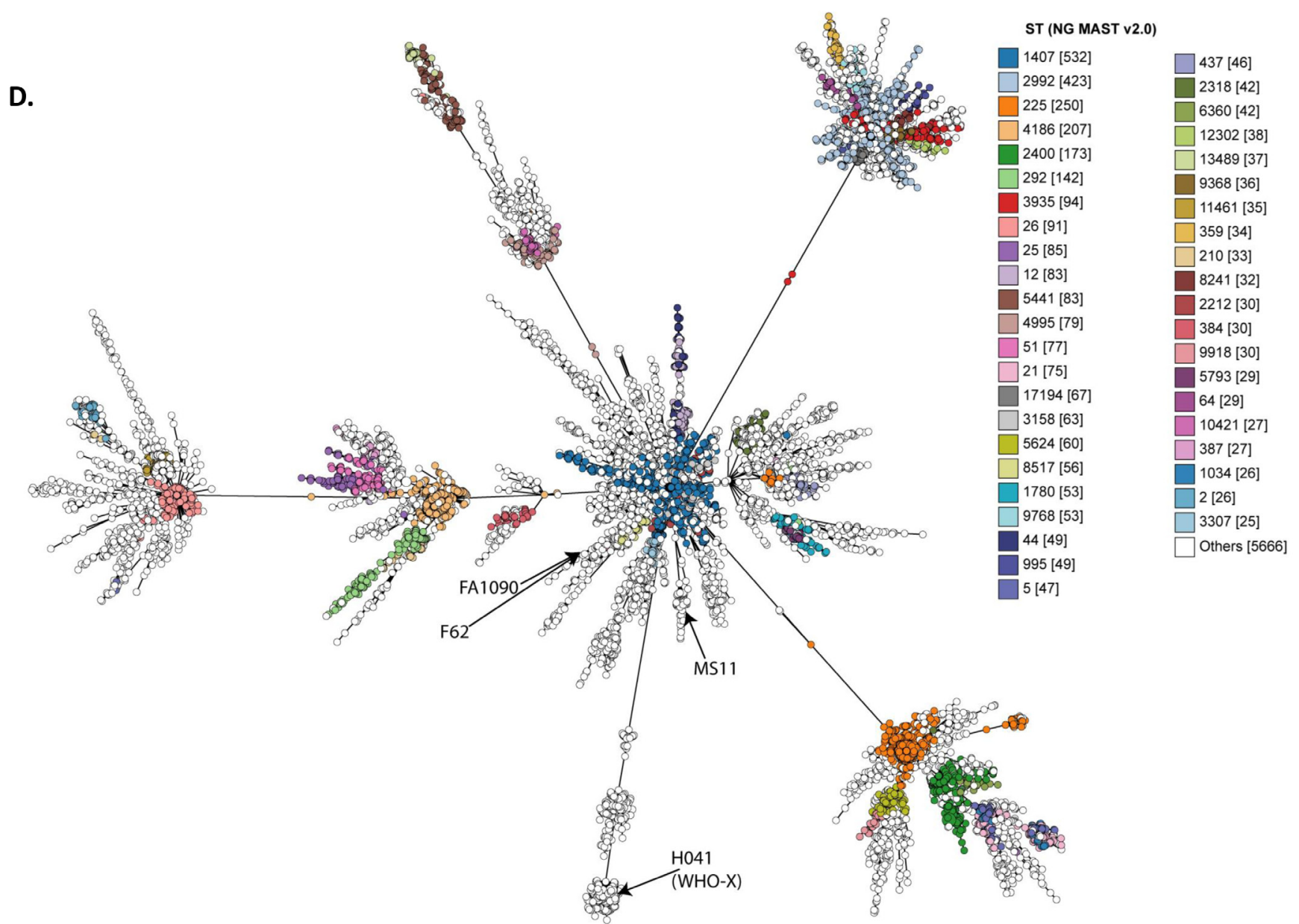

Figure 2. Minimum spanning trees comparing gonococcal whole genome sequence (WGS) using the core genome. In total, 9206 gonococcal WGSs were compared using the core genome (Neisseria gonorrhoeae cgMLST) and visualised with minimum spanning trees generated using Grapetree ${ }^{84,102}$. Isolates are clustered on the basis of similarities in allelic profiles in the core genome. (A) Nodes are coloured by core genome group using the 300 locus differences or fewer threshold. (B) Multi-locus sequence typing sequence type (MLST ST). (C) N. gonorrhoeae sequence typing for antimicrobial resistance type (NG STAR) ${ }^{88}$. (D) Neisseria gonorrhoeae multi-antigen sequence typing scheme (NG MAST ST v2.0) ${ }^{82}$. Gonococci possessing the same MLST ST while having distinct core genome content are evident, particularly for MLST ST-1901 (indicated by dark blue closed circles) and ST-7363 (dark orange and dashed arrows). This visualisation also makes associations between core genome and NG STAR STs apparent. Numbers in brackets refer to the number of isolates belonging to that group. Legends depict only groups containing 10 to 20 (or more) isolates. Commonly used laboratory strains FA1090, F62 and MS11 are indicated as well as the resistant strain $\mathrm{H} 041$ first identified in Japan.

which fluctuates over time, probably as a consequence of changing natural immunity or vaccination or both ${ }^{103-105}$. However, it is apparent that other modes of selection are exerted on the gonococcal population, and AMR is a major influencing factor ${ }^{96}$. This was shown in the high prevalence of plasmid-mediated AMR in gonococci originating from low- and middle-income countries where, more often than not, syndromic management of gonorrhoea, including treatment with doxycycline, exists ${ }^{106}$. As a result, positive selection of gonococci harbouring conjugative plasmids expressing TetM occurs, resulting in the high prevalence of plasmid-mediated $\mathrm{AMR}^{44}$. That study also identified an association between plasmid types and the core genome, providing further evidence for the presence of structure within the gonococcal population.

The availability of WGS has had a major impact in enhancing our understanding of the population biology of the gonococcus and provides hope that it may be possible in the near future to curb transmission through the identification of gonococcal lineages circulating globally. In addition, the identification of loci constituting the core genome, which are common to all gonococci, provides an opportunity to assess antigenic diversity across the gonococcal population, equipping us with novel insights in vaccine development. 


\section{Vaccine development}

The capacity of the gonococcus to become resistant to chemotherapy provides the alarming prospect that this infection will become untreatable in the near future. This has led to a renewed interest in preventing infection through immunisation and vaccine development. However, despite several decades of research in this field, no vaccine has yet been successfully developed for use in humans ${ }^{107}$.

Reasons for the difficulties encountered in gonococcal vaccine development stem from a combination of characteristics exhibited by the gonococcus that facilitate immune evasion? A major challenge is the fact that the gonococcus causes infections solely in humans and it has been difficult to develop animal models of infection in which immune responses and vaccines can be evaluated ${ }^{107}$. However, improvements made in mouse models of infection, including BALB/C, C57BL/6, and genetically engineered mice, have provided insight into the complexities of pathogenesis and the host response elicited ${ }^{107}$. For example, the lack of protective immunity elicited following natural infection may be a consequence of the ability for gonococci to subvert host immune responses ${ }^{108}$. Indeed, studies of experimentally infected female mice indicate that gonococcal infection of the genital tract results in suppression of adaptive Th1- and Th2-governed responses and induction of Th17-driven innate responses, which the gonococcus is able to resist $\mathrm{t}^{107,109,110}$.

Immune evasion is also facilitated by the ability of gonococci to exhibit extensive antigenic diversity in surface-exposed antigens, a consequence of mutation, HGT, and the modulation of expression through phase variation ${ }^{107}$. As a result, appreciable variability will be present both among gonococci and within the same gonococcus over time. For example, intra-chromosomal recombination of promoterless copies of pils that consist of the variable regions of the complete (expressed) pilE gene, which encodes the major pilus subunit (pilin), provides a silent catalogue of sequences that can be reassorted into an expression locus to generate new pilE variants ${ }^{111} . N$. gonorrhoeae is also highly competent for genetic transformation, a process facilitated by a type IV secretion system which is present in over $90 \%$ of gonococci and which, in a contact-independent manner, secretes single-stranded DNA into the environment, providing a source of DNA for HGT ${ }^{112}$.

In spite of these challenges, several $N$. gonorrhoeae antigens, some of which are promising vaccine candidates based on their antigenic conservation, distribution in gonococcal populations, and immunogenicity, have been characterised (Table 2). Several of these antigens have been identified using a combination of bioinformatic and proteomic analyses, which provide novel means of identifying vaccine antigens that would not have been detected using more conventional methods ${ }^{113}$. Indeed, through the use of proteomics-driven reverse vaccinology, the quantitative proteomic analysis of cell envelopes and naturally occurring vesicles has led to the discovery of several additional vaccine candidates, including BamA, LptD, TamA, NGO2054 and NGO2139 ${ }^{114}$, sparking renewed interest in vaccine development (Table 2) ) $^{113}$. However, it is worth noting that a combination of techniques, methods and tools will be required to evaluate vaccine candidates effectively: (i) proteomics to identify the relative abundance, post-translational modifications and protein-protein interactions of those vaccine candidates; (ii) genomics to assess the genetic diversity, prevalence and distribution in gonococcal populations; and (iii) animal models to examine in vivo host responses and the potential for an immune response to be elicited.

It is likely that vaccines containing a 'cocktail' of antigens will be required in order to generate broad protection against the $N$. gonorrhoeae population. In this respect, outer membrane vesicle (OMV) vaccines may be suitable since they contain many of the gonococcal surface antigens in their natural conformation $^{115,116}$. Support for the use of OMV as vaccines comes with the epidemiological evidence provided by a retrospective case control study undertaken in New Zealand, which suggested that individuals vaccinated with the OMV vaccine MeNZB were less likely to contract gonorrhoea ${ }^{117}$. The MeNZB vaccine had been specifically designed in response to a serogroup B $N$. meningitidis epidemic in New Zealand, and although vaccine efficacy towards gonorrhoea was estimated to be $31 \%$, ensuing studies have shown that cross-reactive anti-gonococcal antibodies are induced by MeNZB OMV proteins, providing hope that a gonococcal OMV vaccine is achievable ${ }^{118}$.

A vaccine targeting gonococci is now a possibility with the availability of WGS allowing an in silico appraisal of vaccine candidates to be undertaken prior to more costly and time-consuming vaccine development approaches. In particular, the gene-by-gene characterisation of the gonococcal core genome available on PubMLST allows the diversity of putative vaccine candidates to be catalogued across global gonococcal populations spanning decades ${ }^{84,119,120}$.

\section{Conclusions}

Gonorrhoea has been long considered to be an ancient human disease on the basis of clinical descriptions, but recent research has suggested that the emergence of gonorrhoea may date back to as recently as the sixteenth century, calculated through the comparison of genome sequence data and through inference of the time to most recent common ancestor ${ }^{96}$. However, it is conceivable that a much longer association, potentially spanning millennia and consistent with descriptions in ancients texts, has existed ${ }^{121}$.

In any case, the coexistence of humans and gonococci has had, and will continue to have, a profound effect on both populations. In humans, effects include reduced birth rates resulting from infertility caused by ascending gonococcal infections, in addition to increased mortality rates through coinfection with $\mathrm{HIV}^{122}$. The coexistence of gonococci with humans has led to the development of multiple mechanisms of genetic and antigenic variation, allowing adaptation, persistence and evasion of both environmental and host challenges. In addition, it is most likely that human migration has widened the gonococcal 

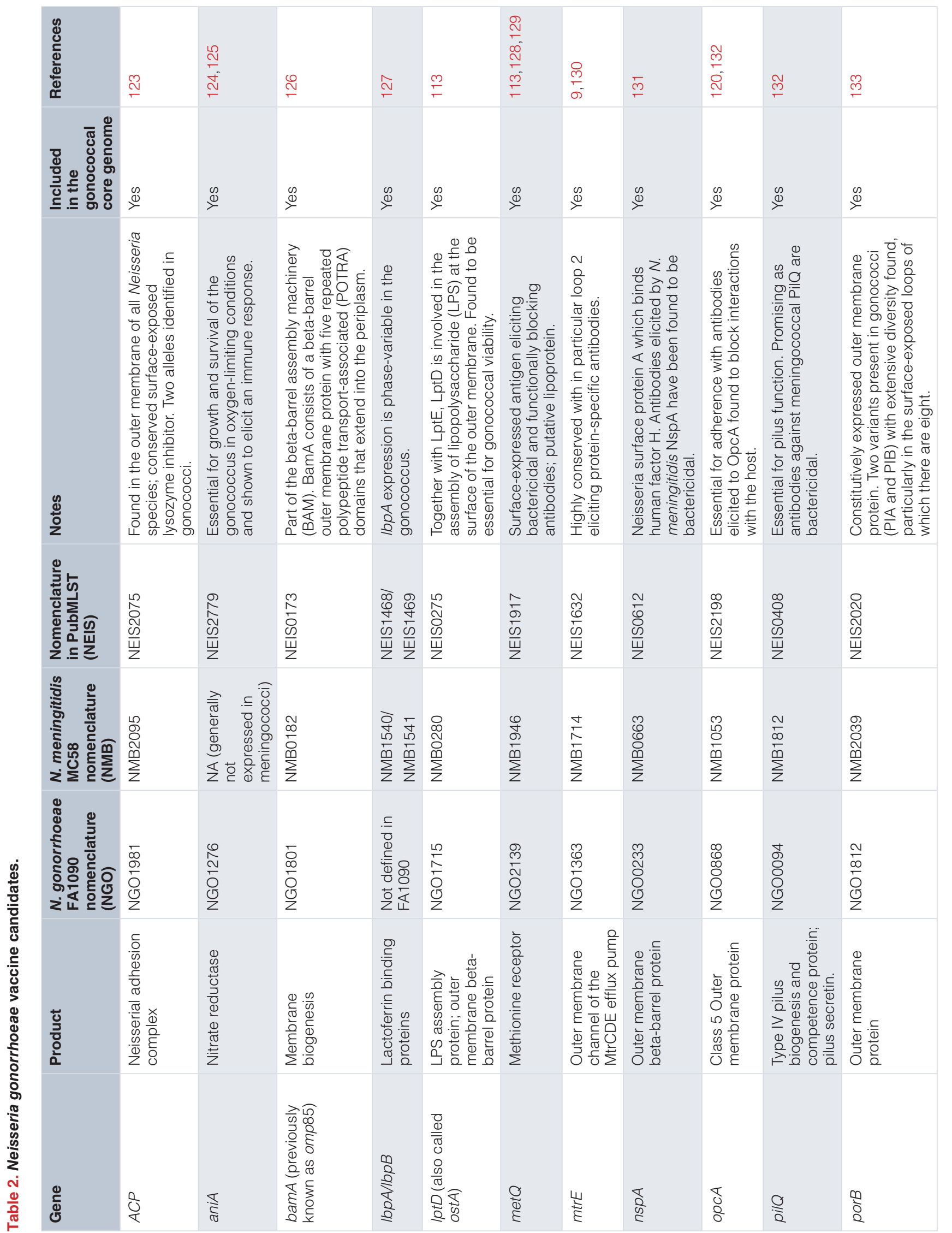


\begin{tabular}{|c|c|c|c|c|c|c|c|c|c|}
\hline 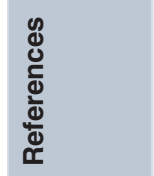 & 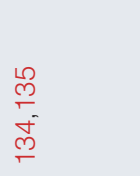 & $\begin{array}{l}\stackrel{\infty}{\stackrel{m}{r}} \\
\end{array}$ & $\stackrel{\stackrel{N}{N}}{\stackrel{2}{2}}$ & $\hat{\underline{m}}$ & 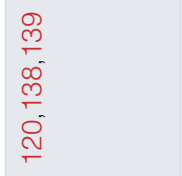 & $\stackrel{\infty}{\circ}$ & $\begin{array}{l}\stackrel{f}{c} \\
\infty^{-} \\
\stackrel{0}{c}\end{array}$ & $\frac{\stackrel{O}{+}}{\frac{1}{+}}$ & $\underset{\leftarrow}{\stackrel{f}{+}}$ \\
\hline 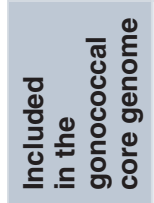 & $\stackrel{\infty}{\rightleftharpoons}$ & $\stackrel{\mathscr{\infty}}{\succ}$ & $\stackrel{\infty}{\nu}$ & $\stackrel{\infty}{\rightleftharpoons}$ & $\stackrel{\infty}{\rightleftharpoons}$ & $\stackrel{\infty}{\longleftarrow}$ & $\stackrel{\infty}{\nu}$ & io & $\stackrel{\infty}{\rightleftharpoons}$ \\
\hline 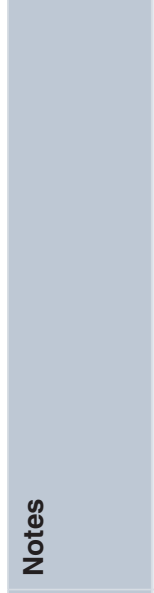 & 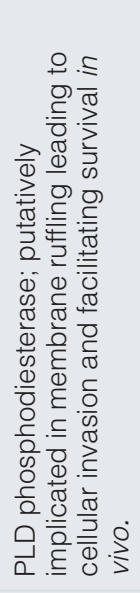 & 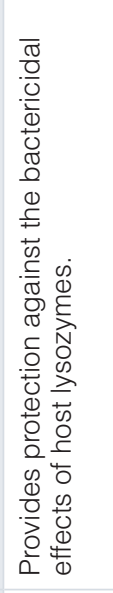 & 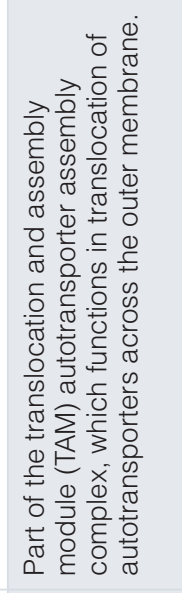 & 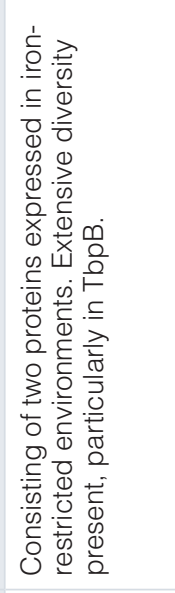 & 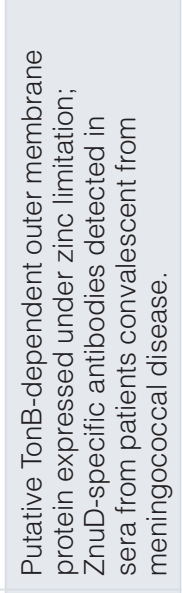 & 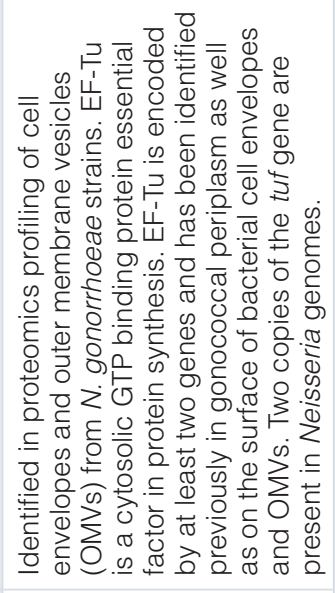 & 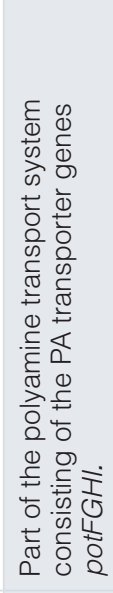 & 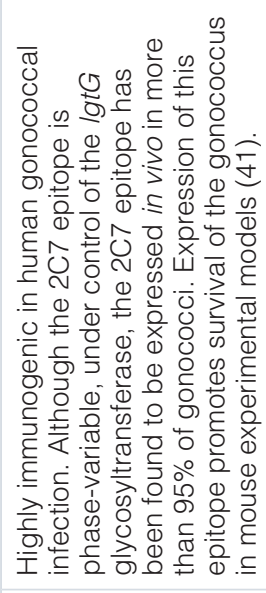 & 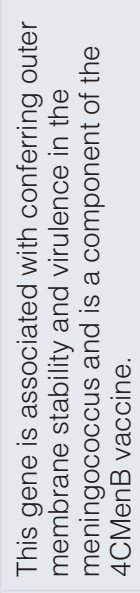 \\
\hline 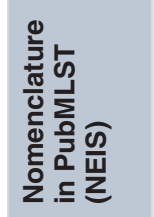 & $\begin{array}{l}\infty \\
0 \\
\infty \\
\frac{\infty}{\omega} \\
\underline{Z}\end{array}$ & $\begin{array}{l}\stackrel{\mathscr{N}}{N} \\
\frac{\tilde{N}}{\mathscr{N}} \\
\frac{\vec{W}}{Z}\end{array}$ & 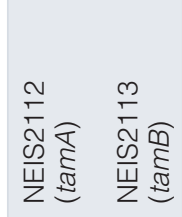 & 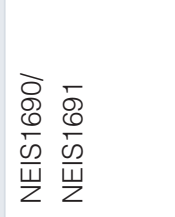 & 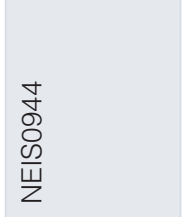 & 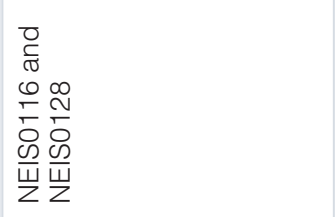 & $\begin{array}{l}0 \\
\infty \\
60 \\
\frac{0}{0} \\
\underline{Z}\end{array}$ & 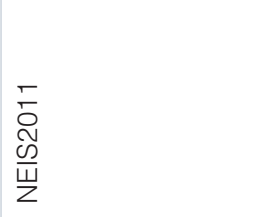 & 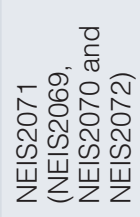 \\
\hline 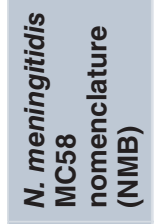 & 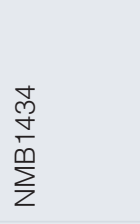 & 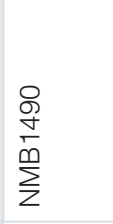 & 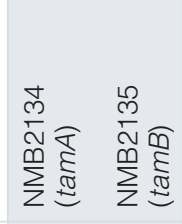 & 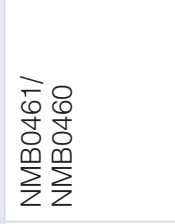 & $\begin{array}{l}\text { D } \\
0 \\
0 \\
\sum_{\Sigma}^{\infty}\end{array}$ & $z$ & $\Sigma$ & $\mathbb{z}$ & 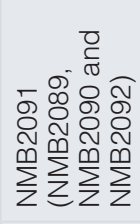 \\
\hline 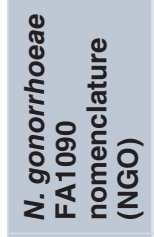 & $\begin{array}{l}\text { ণे } \\
8 \\
8 \\
0 \\
0\end{array}$ & $\begin{array}{l}0 \\
8 \\
0 \\
0 \\
0\end{array}$ & 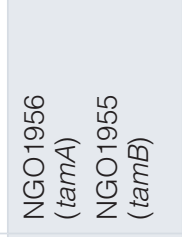 & 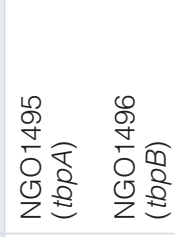 & 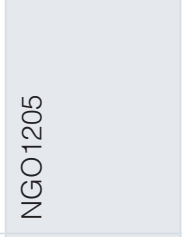 & 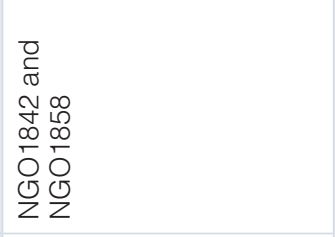 & 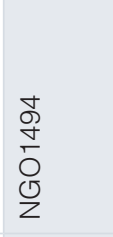 & 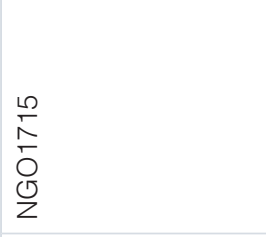 & 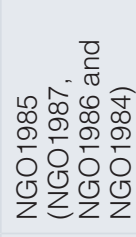 \\
\hline 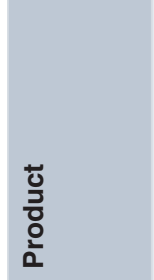 & $\begin{array}{l}0 \\
0 \\
0 \\
\frac{0}{0} \\
\stackrel{0}{\overline{0}} \\
\frac{0}{0} \\
\frac{0}{0} \\
0 \\
\frac{0}{0}\end{array}$ & 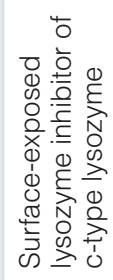 & 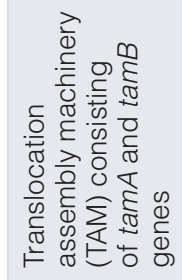 & 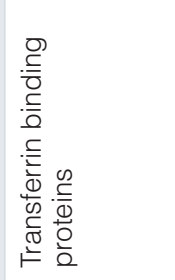 & 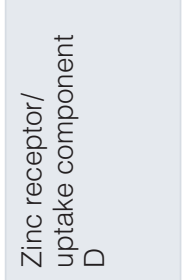 & 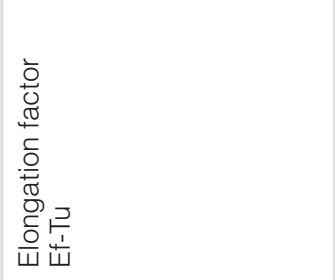 & 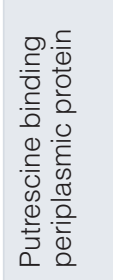 & 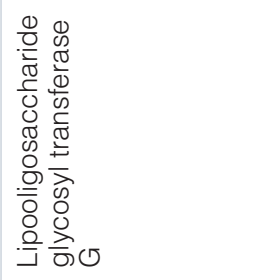 & 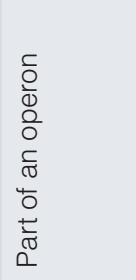 \\
\hline 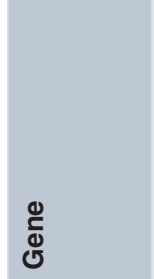 & $\frac{\partial}{2}$ & $\frac{\bar{\omega}}{\omega}$ & 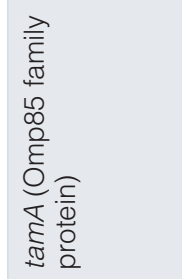 & $\begin{array}{l}0 \\
0 \\
2 \\
\frac{2}{2} \\
0 \\
0 \\
2\end{array}$ & 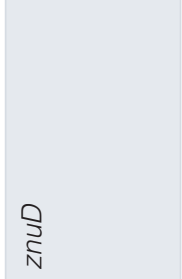 & ミ & 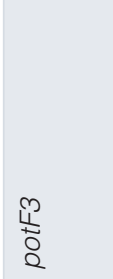 & 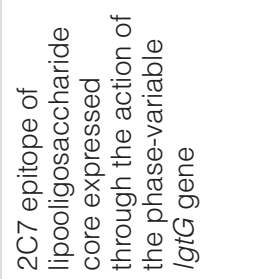 & 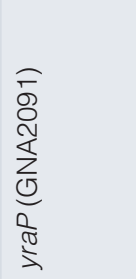 \\
\hline
\end{tabular}


gene pool with increased diversity as a result ${ }^{145}$. In more recent times, antimicrobial use has further shaped the gonococcal population, leading to the expansion of AMR lineages ${ }^{84,96}$.

Genomics plays an increasingly important role in combatting gonococcal disease, allowing the definition and characterisation of complex characters, including the genetic elements associated with AMR, persistence and antigenic diversity. However, at the time of writing, only a very small proportion of gonococci causing infection were analysed by WGS. For example, 56,259 infections were diagnosed in England in 2018 and it would be both expensive and impractical to sequence or culture all of these in one year using current sequencing platforms. Therefore, a large proportion of the $N$. gonorrhoeae isolates circulating globally will remain uncharacterised at the WGS level for the near future. Our current understanding will be based on a subset of the gonococcal population and at the time of writing this was strongly biased towards isolates with an AMR phenotype. To further our ability to cure or prevent gonorrhoea, larger and more representative datasets need to be assembled and sequenced. Sequencing technology has made major advances in the last decade and what seems impossible now may be achievable in the future. Until then, it is likely that the gonococcus will continue to elude us.

\section{Abbreviations}

AMR, antimicrobial resistance; BAPS, Bayesian Analysis of Population Structure; cc, clonal complex; ESC, extendedspectrum cephalosporin; EU/EEA, European Union/European Economic Area; HGT, horizontal gene transfer; MDR-GC, multidrug-resistant gonococci; MIC, minimum inhibition concentration; MLST, multi-locus sequence typing; NG MAST, Neisseria gonorrhoeae multi-antigen sequence typing; NG STAR, Neisseria gonorrhoeae sequence typing for antimicrobial resistance; OMV, outer membrane vesicle; ST, sequence type; XDR-GC, extensively drug-resistant gonococci; WGS, whole genome sequencing
1. W Wi T, Lahra MM, Ndowa F, et al.: Antimicrobial resistance in Neisseria gonorrhoeae: Global surveillance and a call for international collaborative action. PLoS Med. 2017; 14(7): e1002344.

PubMed Abstract | Publisher Full Text | Free Full Text |

Faculty Opinions Recommendation

2. Unemo M, Del Rio C, Shafer WM: Antimicrobial Resistance Expressed by Neisseria gonorrhoeae: A Major Global Public Health Problem in the 21st Century. Microbiol Spectr. 2016; 4(3).

PubMed Abstract | Publisher Full Text | Free Full Text

3. Unemo M, Seifert HS, Hook 3rd EW, et al.: Gonorrhoea. Nat Rev Dis Primers. 2019; 5(1): 79 .

PubMed Abstract | Publisher Full Text | Faculty Opinions Recommendation

4. World Health Organization (WHO): Global priority list of antibiotic-resistant bacteria to guide research, discovery, and development of new antibiotics. Geneva Switzerland: WHO; 2017

Reference Source

5. Peyriere $\mathrm{H}$, Makinson $\mathrm{A}$, Marchandin $\mathrm{H}$, et al:: Doxycycline in the management of sexually transmitted infections. J Antimicrob Chemother. 2018; 73(3): 553-63. PubMed Abstract | Publisher Full Text

6. Unemo M, Shafer WM: Antimicrobial resistance in Neisseria gonorrhoeae in the 21st century: Past, evolution, and future. Clin Microbiol Rev. 2014; 27(3): 587-613.

PubMed Abstract | Publisher Full Text | Free Full Text

7. Whiley DM, Jennison A, Pearson J, et al.: Genetic characterisation of Neisseria gonorrhoeae resistant to both ceftriaxone and azithromycin. Lancet Infect Dis. 2018; 18(7): 717-8

PubMed Abstract | Publisher Full Text

8. Eyre DW, Sanderson ND, Lord E, et al:: Gonorrhoea treatment failure caused by a Neisseria gonorrhoeae strain with combined ceftriaxone and high-level azithromycin resistance, England, February 2018. Euro Surveill. 2018; 23(27): 1800323.

PubMed Abstract | Publisher Full Text | Free Full Text

9. Rice PA, Shafer WM, Ram S, et al:: Neisseria gonorrhoeae: Drug Resistance, Mouse Models, and Vaccine Development. Annu Rev Microbiol. 2017; 71 665-86.

PubMed Abstract | Publisher Full Text

10. TESSy TESS: Surveillance atlas of infectious diseases. 2021 Reference Source

11. ECDC: Annual Epidemiological Report for 2017 - Gonorrhoea. Stockholm: European Centre for Disease Prevention and Control; 2017. Reference Source

12. CDC: Gonorrhoea. CDC; 2017. Reference Source

13. The Kirby Institute: HIV, viral hepatitis and sexually transmissable infections in
Australia: Annual Surveillance Report 2017. Sydney: The Kirby Institute, UNSW Australia; 2017.

Reference Source

14. Yue XL, Gong XD, Li J, et al.: Gonorrhea in China, 2018. Int J Dermatol Venereol. 2019; 2(2): 65-9.

Publisher Full Text | Faculty Opinions Recommendation

15. Kawado M, Hashimoto S, Ohta A, et al.: Estimating nationwide cases of sexually transmitted diseases in $\mathbf{2 0 1 5}$ from sentinel surveillance data in Japan. BMC Infect Dis. 2020; 20(1): 77.

PubMed Abstract | Publisher Full Text | Free Full Text

Faculty Opinions Recommendation

16. Unemo M, Lahra MM, Cole M, et al.: World Health Organization Global Gonococcal Antimicrobial Surveillance Program (WHO GASP): Review of new data and evidence to inform international collaborative actions and research efforts. Sex Health. 2019; 16(5): 412-25.

PubMed Abstract | Publisher Full Text | Free Full Text |

Faculty Opinions Recommendation

17. Ashford WA, Golash RG, Hemming VG: Penicillinase-producing Neisseria gonorrhoeae. Lancet. 1976; 2(7987): 657-8.

PubMed Abstract | Publisher Full Text

18. Cehovin A, Lewis SB: Mobile genetic elements in Neisseria gonorrhoeae: Movement for change. Pathog Dis. 2017; 75(6). PubMed Abstract | Publisher Full Text

19. Dillon JA, Yeung KH: Beta-lactamase plasmids and chromosomally mediated antibiotic resistance in pathogenic Neisseria species. Clin Microbiol Rev. 1989; 2 Suppl(Suppl): S125-33

PubMed Abstract | Publisher Full Text | Free Full Text

20. Morse SA, Johnson SR, Biddle JW, et al.: High-level tetracycline resistance in Neisseria gonorrhoeae is result of acquisition of streptococcal tetM determinant. Antimicrob Agents Chemother. 1986; 30(5): 664-70. PubMed Abstract | Publisher Full Text | Free Full Text

21. Pachulec E, van der Does C: Conjugative plasmids of Neisseria gonorrhoeae. PLoS One 2010: 5(4): e9962.

PubMed Abstract | Publisher Full Text | Free Full Text

22. Belland RJ, Morrison SG, Ison C, et al:: Neisseria gonorrhoeae acquires mutations in analogous regions of gyrA and parC in fluoroquinolone-resistant isolates. Mol Microbiol. 1994; 14(2): 371-80. PubMed Abstract | Publisher Full Text

23. Hall CL, Harrison MA, Pond MJ, et al:: Genotypic determinants of fluoroquinolone and macrolide resistance in Neisseria gonorrhoeae. Sex Health. 2019; 16(5): 479-87.

PubMed Abstract | Publisher Full Text

24. Tanaka M, Takahashi K, Saika T, et al.: Development of fluoroquinolone resistance and mutations involving GyrA AND ParC proteins among Neisseria 
gonorrhoeae isolates in Japan. J Urol. 1998; 159(6): 2215-9. PubMed Abstract | Publisher Full Text

25. Lindbäck E, Rahman M, Jalal S, et al:: Mutations in gyrA, gyrB, parC, and parE in quinolone-resistant strains of Neisseria gonorrhoeae. APMIS. 2002; 110(9): $651-7$.

PubMed Abstract | Publisher Full Text

26. Lindberg R, Fredlund $\mathrm{H}$, Nicholas $\mathrm{R}$, et al.: Neisseria gonorrhoeae isolates with reduced susceptibility to cefixime and ceftriaxone: Association with genetic polymorphisms in penA, mtrR, porB1b, and ponA. Antimicrob Agents Chemother. 2007; 51(6): 2117-22.

PubMed Abstract | Publisher Full Text | Free Full Text

27. Ropp PA, Hu M, Olesky M, et al:: Mutations in ponA, the gene encoding penicillin-binding protein 1 , and a novel locus, penC, are required for highlevel chromosomally mediated penicillin resistance in Neisseria gonorrhoeae. Antimicrob Agents Chemother. 2002; 46(3): 769-77.

PubMed Abstract | Publisher Full Text | Free Full Text

28. Seike K, Yasuda M, Hatazaki K, et al:: Novel penA mutations identified in Neisseria gonorrhoeae with decreased susceptibility to ceftriaxone isolated between 2000 and 2014 in Japan. J Antimicrob Chemother. 2016; 71(9): 2466-70. PubMed Abstract | Publisher Full Text

29. Grad YH, Harris SR, Kirkcaldy RD, et al:: Genomic Epidemiology of Gonococcal Resistance to Extended-Spectrum Cephalosporins, Macrolides, and Fluoroquinolones in the United States, 2000-2013. J Infect Dis. 2016; 214(10): 1579-87.

PubMed Abstract | Publisher Full Text | Free Full Text

30. Ohnishi M, Watanabe $\mathrm{Y}$, Ono $\mathrm{E}$, et al.: Spread of a chromosomal cefiximeresistant penA gene among different Neisseria gonorrhoeae lineages. Antimicrob Agents Chemother. 2010; 54(3): 1060-7.

PubMed Abstract | Publisher Full Text | Free Full Text

31. Yahara K, Ma KC, Mortimer TD, et al.: Emergence and evolution of antimicrobia resistance genes and mutations in Neisseria gonorrhoeae. Genome Med. 2021; 13(1): 51 .

PubMed Abstract | Publisher Full Text | Free Full Tex

32. Palace SG, Wang $\mathrm{Y}$, Rubin $\mathrm{DH}$, et al:: RNA polymerase mutations cause cephalosporin resistance in clinical Neisseria gonorrhoeae isolates. eLife. 2020; 9: e51407.

PubMed Abstract | Publisher Full Text | Free Full Text |

Faculty Opinions Recommendation

33. Galimand M, Gerbaud G, Courvalin P: Spectinomycin resistance in Neisseria spp. due to mutations in 16S rRNA. Antimicrob Agents Chemother. 2000; 44(5): $1365-6$.

PubMed Abstract | Publisher Full Text | Free Full Text

34. Chisholm SA, Dave J, Ison CA: High-level azithromycin resistance occurs in Neisseria gonorrhoeae as a result of a single point mutation in the 23S rRNA genes. Antimicrob Agents Chemother. 2010; 54(9): 3812-6.

PubMed Abstract | Publisher Full Text | Free Full Text

35. Galarza PG, Abad R, Canigia LF, et al:: New mutation in 23S rRNA gene associated with high level of azithromycin resistance in Neisseria gonorrhoeae. Antimicrob Agents Chemother. 2010; 54(4): 1652-3. PubMed Abstract | Publisher Full Text | Free Full Text

36. Gill MJ, Simjee S, Al-Hattawi K, et al:: Gonococcal resistance to beta-lactams and tetracycline involves mutation in loop 3 of the porin encoded at the penB locus. Antimicrob Agents Chemother. 1998; 42(11): 2799-803. PubMed Abstract | Publisher Full Text | Free Full Text

37. Veal WL, Nicholas RA, Shafer WM: Overexpression of the MtrC-MtrD-MtrE efflux pump due to an $m$ trR mutation is required for chromosomally mediated penicillin resistance in Neisseria gonorrhoeae. J Bacteriol. 2002; 184(20): 5619-24.

PubMed Abstract | Publisher Full Text | Free Full Text

38. Zarantonelli L, Borthagaray G, Lee EH, et al.: Decreased azithromycin susceptibility of Neisseria gonorrhoeae due to mtrR mutations. Antimicrob Agents Chemother. 1999; 43(10): 2468-72.

PubMed Abstract | Publisher Full Text | Free Full Text

39. Warner DM, Shafer WM, Jerse AE: Clinically relevant mutations that cause derepression of the Neisseria gonorrhoeae MtrC-MtrD-MtrE Efflux pump system confer different levels of antimicrobial resistance and in vivo fitness. Mol Microbiol. 2008; 70(2): 462-78.

PubMed Abstract | Publisher Full Text | Free Full Text

40. Wadsworth CB, Arnold BJ, Sater MRA, et al.: Azithromycin Resistance through Interspecific Acquisition of an Epistasis-Dependent Efflux Pump Component and Transcriptional Regulator in Neisseria gonorrhoeae. mBio. 2018; 9(4): e01419-18.

PubMed Abstract | Publisher Full Text | Free Full Text |

Faculty Opinions Recommendation

41. Spratt BG: Hybrid penicillin-binding proteins in penicillin-resistant strains of Neisseria gonorrhoeae. Nature. 1988; 332(6160): 173-6. PubMed Abstract | Publisher Full Text

42. Spratt BG, Zhang QY, Jones DM, et al.: Recruitment of a penicillin-binding protein gene from Neisseria flavescens during the emergence of penicillin resistance in Neisseria meningitidis. Proc Natl Acad Sci U S A. 1989; 86(22): 8988-92.

PubMed Abstract | Publisher Full Text | Free Full Text

43. Dowson CG, Hutchison A, Brannigan JA, et al.: Horizontal transfer of penicillin-binding protein genes in penicillin-resistant clinical isolates of Streptococcus pneumoniae. Proc Natl Acad Sci U S A. 1989; 86(22): 8842-6. PubMed Abstract | Publisher Full Text | Free Full Text

44. Cehovin A, Jolley KA, Maiden MCJ, et al:: Association of Neisseria gonorrhoeae Plasmids With Distinct Lineages and The Economic Status of Their Country of Origin. J Infect Dis. 2020; 222(11): 1826-36.

PubMed Abstract | Publisher Full Text | Free Full Text

45. Bush K: Past and Present Perspectives on $\beta$-Lactamases. Antimicrob Agents Chemother. 2018; 62(10): e01076-18.

PubMed Abstract | Publisher Full Text | Free Full Text

46. Dillon JR, Pauzé M, Yeung KH: Molecular and epidemiological analysis of penicillinase producing strains of Neisseria gonorrhoeae isolated in Canada 1976-84: Evolution of new auxotypes and beta lactamase encoding plasmids. Genitourin Med. 1986; 62(3): 151-7.

PubMed Abstract | Publisher Full Text | Free Full Text

47. Singh R, Perera SR, Katselis GS, et al:: A $\beta$-lactamase-producing plasmid from Neisseria gonorrhoeae carrying a unique 6 bp deletion in blaTEM-1 encoding a truncated $24 \mathrm{kDa}$ TEM-1 penicillinase that hydrolyses ampicillin slowly. $J$ Antimicrob Chemother. 2019; 74(10): 2904-12.

PubMed Abstract | Publisher Full Text

48. Marquez CM, Dillon JAR, Rodriguez V, et al: Detection of a novel TetM determinant in tetracycline-resistant Neisseria gonorrhoeae from Uruguay, 1996-1999. Sex Transm Dis. 2002; 29(12): 792-7. PubMed Abstract | Publisher Full Text

49. Unemo M, Shafer WM: Antibiotic resistance in Neisseria gonorrhoeae: Origin, evolution, and lessons learned for the future. Ann N Y Acad Sci. 2011; 1230: E19-28.

PubMed Abstract | Publisher Full Text | Free Full Text

50. Qvarnström Y, Swedberg G: Sulphonamide resistant commensal Neisseria with alterations in the dihydropteroate synthase can be isolated from carriers not exposed to sulphonamides. BMC Microbiol. 2002; 2: 34. PubMed Abstract | Publisher Full Text | Free Full Text

51. Zapun A, Morlot C, Taha MK: Resistance to $\beta$-Lactams in Neisseria ssp Due to Chromosomally Encoded Penicillin-Binding Proteins. Antibiotics (Basel). 2016; 5(4): 35

PubMed Abstract | Publisher Full Text | Free Full Text

52. Unemo M, Golparian D, Nicholas R, et al:: High-level cefixime- and ceftriaxoneresistant Neisseria gonorrhoeae in France: Novel penA mosaic allele in a successful international clone causes treatment failure. Antimicrob Agents Chemother. 2012; 56(3): 1273-80.

PubMed Abstract | Publisher Full Text | Free Full Text

53. Ohneck EA, Zalucki YM, Johnson PJT, et al:: A novel mechanism of high-level, broad-spectrum antibiotic resistance caused by a single base pair change in Neisseria gonorrhoeae. mBio. 2011; 2(5): e00187-11.

PubMed Abstract | Publisher Full Text | Free Full Text

54. Hagman KE, Pan W, Spratt BG, et al:: Resistance of Neisseria gonorrhoeae to antimicrobial hydrophobic agents is modulated by the mtrRCDE efflux system. Microbiology (Reading). 1995; 141(Pt 3): 611-22.

PubMed Abstract | Publisher Full Text

55. Olesky M, Hobbs M, Nicholas RA: Identification and analysis of amino acid mutations in porin IB that mediate intermediate-level resistance to penicillin and tetracycline in Neisseria gonorrhoeae. Antimicrob Agents Chemother. 2002 ; 46(9): 2811-20.

PubMed Abstract | Publisher Full Text | Free Full Text

56. Kivata MW, Mbuchi M, Eyase FL, et al:: gyrA and parC mutations in fluoroquinolone-resistant Neisseria gonorrhoeae isolates from Kenya. BMC Microbiol. 2019; 19(1): 76.

PubMed Abstract | Publisher Full Text | Free Full Text

57. Demczuk W, Martin I, Peterson S, et al.: Genomic Epidemiology and Molecular Resistance Mechanisms of Azithromycin-Resistant Neisseria gonorrhoeae in Canada from 1997 to 2014. J Clin Microbiol. 2016; 54(5): 1304-13. PubMed Abstract | Publisher Full Text | Free Full Text

58. Whiley DM, Kundu RL, Jennison AV, et al:: Azithromycin-resistant Neisseria gonorrhoeae spreading amongst men who have sex with men (MSM) and heterosexuals in New South Wales, Australia, 2017. J Antimicrob Chemother. 2018; 73(5): 1242-6.

PubMed Abstract | Publisher Full Text

59. Trembizki E, Doyle C, Jennison A, et al:: A Neisseria gonorrhoeae strain with a meningococcal mtrR sequence. J Med Microbiol. 2014; 63(Pt 8): 1113-5. PubMed Abstract | Publisher Full Text

60. Unemo M, Golparian D, Skogen V, et al.: Neisseria gonorrhoeae strain with high-level resistance to spectinomycin due to a novel resistance mechanism (mutated ribosomal protein S5) verified in Norway. Antimicrob Agents Chemother. 2013; 57(2): 1057-61. PubMed Abstract | Publisher Full Text | Free Full Text

61. Ng LK, Martin I, Liu G, et al:: Mutation in 23S rRNA associated with macrolide resistance in Neisseria gonorrhoeae. Antimicrob Agents Chemother. 2002; 46(9): 3020-5.

PubMed Abstract | Publisher Full Text | Free Full Text

62. Unemo M, Golparian D, Hellmark B: First three Neisseria gonorrhoeae isolates with high-level resistance to azithromycin in Sweden: A threat to currently available dual-antimicrobial regimens for treatment of gonorrhea? Antimicrob Agents Chemother. 2014; 58(1): 624-5.

PubMed Abstract | Publisher Full Text | Free Full Text 
63. Ilina EN, Malakhova MV, Bodoev IN, et al.: Mutation in ribosomal protein S5 leads to spectinomycin resistance in Neisseria gonorrhoeae. Front Microbiol. 2013; 4: 186.

PubMed Abstract | Publisher Full Text | Free Full Text

64. Colesen SW, Grad YH: Deciphering the Impact of Bystander Selection for Antibiotic Resistance in Neisseria gonorrhoeae. J Infect Dis. 2020; 221(7): 1033-5.

PubMed Abstract | Publisher Full Text | Free Full Text |

Faculty Opinions Recommendation

65. Kenyon C, Buyze J, Spiteri G, et al.: Population-Level Antimicrobial Consumption Is Associated With Decreased Antimicrobial Susceptibility in Neisseria gonorrhoeae in 24 European Countries: An Ecological Analysis. $J$ Infect Dis. 2020; 221(7): 1107-16.

PubMed Abstract | Publisher Full Text | Faculty Opinions Recommendation

66. Olesen SW, Torrone EA, Papp JR, et al:: Azithromycin Susceptibility Among Neisseria gonorrhoeae Isolates and Seasonal Macrolide Use. J Infect Dis. 2019; 219(4): 619-23.

PubMed Abstract | Publisher Full Text | Free Full Text |

Faculty Opinions Recommendation

67. Tapsall JW, Ndowa F, Lewis DA, et al:: Meeting the public health challenge of multidrug- and extensively drug-resistant Neisseria gonorrhoeae. Expert Rev Anti Infect Ther. 2009; 7(7): 821-34.

PubMed Abstract | Publisher Full Text

68. Martin I, Sawatzky P, Allen V, et al.: Multidrug-resistant and extensively drugresistant Neisseria gonorrhoeae in Canada, 2012-2016. Can Commun Dis Rep. 2019; 45(2-3): 45-53.

PubMed Abstract | Publisher Full Text | Free Full Text

69. Fifer $\mathrm{H}$, Cole $\mathrm{M}$, Hughes $\mathrm{G}$, et al.: Sustained transmission of high-level azithromycin-resistant Neisseria gonorrhoeae in England: An observational study. Lancet Infect Dis. 2018; 18(5): 573-81.

PubMed Abstract | Publisher Full Text

70. Kwong JC, Chow EPF, Stevens $\mathrm{K}$, et al.: Whole-genome sequencing reveals transmission of gonococcal antibiotic resistance among men who have sex with men: An observational study. Sex Transm Infect. 2018; 94(2): 151-7. PubMed Abstract | Publisher Full Text | Free Full Text

71. Hunt M, Mather AE, Sánchez-Busó L, et al:: ARIBA: Rapid antimicrobial resistance genotyping directly from sequencing reads. Microb Genom. 2017; 3(10): e000131.

PubMed Abstract | Publisher Full Text | Free Full Text

72. Pathogenwatch.

Reference Source

73. Sánchez-Busó L, Yeats CA, Taylor B, et al: A community-driven resource for genomic epidemiology and antimicrobial resistance prediction of Neisseria gonorrhoeae at Pathogenwatch. Genome Med. 2021; 13(1): 61. PubMed Abstract | Publisher Full Text | Free Full Text | Faculty Opinions Recommendation

74. Abricate.

Reference Source

75. Zankari $\mathrm{E}$, Hasman $\mathrm{H}$, Cosentino $\mathrm{S}$, et al:: Identification of acquired antimicrobial resistance genes. J Antimicrob Chemother. 2012; 67(11): 2640-4. PubMed Abstract | Publisher Full Text | Free Full Text

76. Jia B, Raphenya AR, Alcock B, et al:: CARD 2017: Expansion and model-centric curation of the comprehensive antibiotic resistance database. Nucleic Acids Res. 2017; 45(D1): D566-D573.

PubMed Abstract | Publisher Full Text | Free Full Text

77. Hendriksen RS, Bortolaia V, Tate H, et al:: Using Genomics to Track Global Antimicrobial Resistance. Front Public Health. 2019; 7: 242. PubMed Abstract | Publisher Full Text | Free Full Text | Faculty Opinions Recommendation

78. Nown K, Harris S, Sánchez-Busó L, et al.: Genomic and Phenotypic Variability in Neisseria gonorrhoeae Antimicrobial Susceptibility, England. Emerg Infect Dis. 2020; 26(3): 505-15. PubMed Abstract | Publisher Full Text | Free Full Text | Faculty Opinions Recommendation

79. Alfsnes K, Eldholm V, Olsen AO, et al.: Genomic epidemiology and population structure of Neisseria gonorrhoeae in Norway, 2016-2017. Microb Genom. 2020; 6(4): e000359.

PubMed Abstract | Publisher Full Text | Free Full Tex

80. Eyre DW, de Silva D, Cole K, et al:: WGS to predict antibiotic MICs for Neisseria gonorrhoeae. J Antimicrob Chemother. 2017; 72(7): 1937-47. PubMed Abstract | Publisher Full Text | Free Full Text

81. Břinda $\mathrm{K}$, Callendrello $\mathrm{A}, \mathrm{Ma} \mathrm{KC}$, et al.: Rapid inference of antibiotic resistance and susceptibility by genomic neighbour typing. Nat Microbiol. 2020; 5(3): 455-64.

PubMed Abstract | Publisher Full Text | Free Full Text

82. Demczuk W, Sidhu S, Unemo M, et al:: Neisseria gonorrhoeae Sequence Typing for Antimicrobial Resistance, a Novel Antimicrobial Resistance Multilocus Typing Scheme for Tracking Global Dissemination of $\boldsymbol{N}$. gonorrhoeae Strains. J Clin Microbiol. 2017; 55(5): 1454-68. PubMed Abstract | Publisher Full Text | Free Full Text

83. Harrison OB, Clemence M, Dillard JP, et al:: Genomic analyses of Neisseria gonorrhoeae reveal an association of the gonococcal genetic island with antimicrobial resistance. $J$ Infect. 2016; 73(6): 578-87. PubMed Abstract | Publisher Full Text | Free Full Text

84. Harrison OB, Cehovin A, Skett J, et al.: Neisseria gonorrhoeae Population Genomics: Use of the Gonococcal Core Genome to Improve Surveillance of Antimicrobial Resistance. J Infect Dis. 2020; 222(11): 1816-25.

PubMed Abstract | Publisher Full Text | Free Full Text

85. C Singh R, Dillon JAR, Demczuk W, et al.: Gen2Epi: An automated wholegenome sequencing pipeline for linking full genomes to antimicrobial susceptibility and molecular epidemiological data in Neisseria gonorrhoeae. BMC Genomics. 2019; 20(1): 165.

PubMed Abstract | Publisher Full Text | Free Full Text | Faculty Opinions Recommendation

86. O'Rourke M, Spratt BG: Further evidence for the non-clonal population structure of Neisseria gonorrhoeae: Extensive genetic diversity within isolates of the same electrophoretic type. Microbiology (Reading). 1994; 140(Pt 6): 1285-90.

PubMed Abstract | Publisher Full Text

87. O'Rourke M, Stevens E: Genetic structure of Neisseria gonorrhoeae populations: A non-clonal pathogen. J Gen Microbiol. 1993; 139(11): 2603-11. PubMed Abstract | Publisher Full Text

88. Martin IMC, Ison CA, Aanensen DM, et al.: Rapid sequence-based identification of gonococcal transmission clusters in a large metropolitan area. $J$ Infect Dis. 2004: 189(8): 1497-505.

PubMed Abstract | Publisher Full Text

89. Bennett JS, Jolley KA, Sparling PF, et al:: Species status of Neisseria gonorrhoeae: Evolutionary and epidemiological inferences from multilocus sequence typing. BMC Biol. 2007; 5: 35. PubMed Abstract | Publisher Full Text | Free Full Text

90. Maiden MC, Bygraves JA, Feil E, et al:: Multilocus sequence typing: A portable approach to the identification of clones within populations of pathogenic microorganisms. Proc Natl Acad Sci U S A. 1998; 95(6): 3140-5. PubMed Abstract | Publisher Full Text | Free Full Text

91. Read RC: Neisseria meningitidis; clones, carriage, and disease. Clin Microbiol Infect. 2014; 20(5): 391-5.

PubMed Abstract | Publisher Full Text

92. Caugant DA, Maiden MCJ: Meningococcal carriage and disease--population biology and evolution. Vaccine. 2009; 27 Suppl 2(4): B64-70. PubMed Abstract | Publisher Full Text | Free Full Text

93. Bratcher HB, Corton C, Jolley KA, et al:: A gene-by-gene population genomics platform: De novo assembly, annotation and genealogical analysis of 108 representative Neisseria meningitidis genomes. BMC Genomics. 2014; 15(1): 1138.

PubMed Abstract | Publisher Full Text | Free Full Text

94. Viscidi RP, Demma JC: Genetic diversity of Neisseria gonorrhoeae housekeeping genes. J Clin Microbiol. 2003; 41(1): 197-204. PubMed Abstract | Publisher Full Text | Free Full Text

95. Smith JM, Smith NH, O'Rourke M, et al.: How clonal are bacteria? Proc Natl Acad SciU S A. 1993: 90(10): 4384-8.

PubMed Abstract | Publisher Full Text | Free Full Text

96. C Sánchez-Busó L, Golparian D, Corander J, et al:: The impact of antimicrobials on gonococcal evolution. Nat Microbiol. 2019; 4(11): 1941-50. PubMed Abstract | Publisher Full Text | Free Full Text | Faculty Opinions Recommendation

97. Lee RS, Seemann T, Heffernan H, et al.: Genomic epidemiology and antimicrobial resistance of Neisseria gonorrhoeae in New Zealand. $J$ Antimicrob Chemother. 2018; 73(2): 353-64. PubMed Abstract | Publisher Full Text | Free Full Text

98. Corander J, Marttinen P, Sirén J, et al:: Enhanced Bayesian modelling in BAPS software for learning genetic structures of populations. BMC Bioinformatics. 2008; 9: 539 .

PubMed Abstract | Publisher Full Text | Free Full Text

99. Croucher NJ, Page AJ, Connor TR, et al.: Rapid phylogenetic analysis of large samples of recombinant bacterial whole genome sequences using Gubbins. Nucleic Acids Res. 2015; 43(3): e15.

PubMed Abstract | Publisher Full Text | Free Full Text

100. Al Suwayyid BA, Coombs GW, Speers DJ, et al.: Genomic epidemiology and population structure of Neisseria gonorrhoeae from remote highly endemic Western Australian populations. BMC Genomics. 2018; 19(1): 165. PubMed Abstract | Publisher Full Text | Free Full Text

101. Ezewudo MN, Joseph SJ, Castillo-Ramirez S, et al.: Population structure of Neisseria gonorrhoeae based on whole genome data and its relationship with antibiotic resistance. PeerJ. 2015; 3: e806. PubMed Abstract | Publisher Full Text | Free Full Text

102. Zhou Z, Alikhan NF, Sergeant MJ, et al:: GrapeTree: Visualization of core genomic relationships among 100,000 bacterial pathogens. Genome Res. 2018; 28(9): 1395-404. PubMed Abstract | Publisher Full Text | Free Full Text

103. A Buckee CO, Jolley KA, Recker M, et al.: Role of selection in the emergence of lineages and the evolution of virulence in Neisseria meningitidis. Proc Nat Acad Sci U S A. 2008; 105(39): 15082-7. PubMed Abstract | Publisher Full Text | Free Full Text | Faculty Opinions Recommendation

104. Gupta S, Anderson RM: Population Structure of Pathogens: The Role of 
Immune Selection. Parasitology Today. 1999; 15(12): 497-501. PubMed Abstract | Publisher Full Text

105. Gupta S, Maiden MC: Exploring the evolution of diversity in pathogen populations. Trends Microbiol. 2001; 9(4): 181-5. PubMed Abstract | Publisher Full Text

106. Cehovin A, Harrison OB, Lewis SB, et al.: Identification of Novel Neisseria gonorrhoeae Lineages Harboring Resistance Plasmids in Coastal Kenya. $J$ Infect Dis. 2018; 218(5): 801-8. PubMed Abstract | Publisher Full Text | Free Full Text

107. Russell MW, Jerse AE, Gray-Owen SD: Progress Toward a Gonococcal Vaccine: The Way Forward. Front Immunol. 2019; 10: 2417. PubMed Abstract | Publisher Full Text | Free Full Text | Faculty Opinions Recommendation

108. Liu Y, Hammer LA, Liu W, et al:: Experimental vaccine induces Th1-driven immune responses and resistance to Neisseria gonorrhoeae infection in a murine model. Mucosal Immunol. 2017; 10(6): 1594-608. PubMed Abstract | Publisher Full Text | Free Full Text

109. Liu Y, Feinen B, Russell MW: New concepts in immunity to Neisseria gonorrhoeae: Innate responses and suppression of adaptive immunity favor the pathogen, not the host. Front Microbiol. 2011; 2: 52 PubMed Abstract | Publisher Full Text | Free Full Text

110. Feinen $\mathrm{B}$, Jerse $\mathrm{AE}$, Gaffen $\mathrm{SL}$, et al:: Critical role of Th17 responses in a murine model of Neisseria gonorrhoeae genital infection. Mucosal Immunol. 2010; 3(3): 312-21.

PubMed Abstract | Publisher Full Text | Free Full Text

111. Hamrick TS, Dempsey JAF, Cohen MS, et al:: Antigenic variation of gonococcal pilin expression in vivo: Analysis of the strain FA1090 pilin repertoire and identification of the pils gene copies recombining with pilE during experimental human infection. Microbiology (Reading). 2001; 147( $\mathrm{Pt} 4$ ): 839-49. PubMed Abstract | Publisher Full Text

112. Hamilton HL, Domínguez NM, Schwartz KJ, et al:: Neisseria gonorrhoeae secretes chromosomal DNA via a novel type IV secretion system. $\mathrm{Mol}$ Microbiol. 2005; 55(6): 1704-21. PubMed Abstract | Publisher Full Text

113. Zielke RA, Wierzbicki IH, Baarda BI, et al.: Proteomics-driven Antigen Discovery for Development of Vaccines Against Gonorrhea. Mol Cell Proteomics. 2016; 15(7): 2338-55.

PubMed Abstract | Publisher Full Text | Free Full Text

114. Zielke RA, Wierzbicki IH, Weber JV, et al:: Quantitative proteomics of the Neisseria gonorrhoeae cell envelope and membrane vesicles for the discovery of potential therapeutic targets. Mol Cell Proteomics. 2014; 13(5): 1299-317. PubMed Abstract | Publisher Full Text | Free Full Text

115. Williams JN, Weynants V, Poolman JT, et al.: Immuno-proteomic analysis of human immune responses to experimental Neisseria meningitidis outer membrane vesicle vaccines identifies potential cross-reactive antigens. Vaccine. 2014; 32(11): 1280-6. PubMed Abstract | Publisher Full Text

116. Schwechheimer $\mathrm{C}$, Kuehn MJ: Outer-membrane vesicles from Gram-negative bacteria: Biogenesis and functions. Nat Rev Microbiol. 2015; 13(10): 605-19. PubMed Abstract | Publisher Full Text | Free Full Text

117. Petousis-Harris $\mathrm{H}$, Paynter J, Morgan J, et al.: Effectiveness of a group $\mathrm{B}$ outer membrane vesicle meningococcal vaccine against gonorrhoea in New Zealand: A retrospective case-control study. Lancet. 2017; 390(10102): 1603-10.

PubMed Abstract | Publisher Full Text

118. Semchenko EA, Tan A, Borrow R, et al.: The Serogroup B Meningococcal Vaccine Bexsero Elicits Antibodies to Neisseria gonorrhoeae. Clin Infect Dis. 2019; 69(7): 1101-11.

PubMed Abstract | Publisher Full Text | Free Full Text

119. Baarda BI, Zielke RA, Nicholas RA, et al.: PubMLST for Antigen Allele Mining to Inform Development of Gonorrhea Protein-Based Vaccines. Front Microbiol. 2018; 9: 2971

PubMed Abstract | Publisher Full Text | Free Full Text

120. Baarda BI, Zielke RA, Holm AK, et al.: Comprehensive Bioinformatic Assessments of the Variability of Neisseria gonorrhoeae Vaccine Candidates. mSphere. 2021; 6(1): e00977-20.

PubMed Abstract | Publisher Full Text | Free Full Text | Faculty Opinions Recommendation

121. Boyd RH: Origin of gonorrhoea and non-specific urethritis. Br J Vener Dis. 1955; 31(4): 246-8.

PubMed Abstract | Publisher Full Text | Free Full Text

122. Ndowa F, Lusti-Narasimhan M: The threat of untreatable gonorrhoea: Implications and consequences for reproductive and sexual morbidity. Reprod Health Matters. 2012; 20(40): 76-82. PubMed Abstract | Publisher Full Text

123. Humbert MV, Awanye AM, Lian LY, et al.: Structure of the Neisseria Adhesin Complex Protein (ACP) and its role as a novel lysozyme inhibitor. PLoS Pathog. 2017; 13(6): e1006448. PubMed Abstract | Publisher Full Text | Free Full Text

124. Shewell LK, Jen FEC, Jennings MP: Refinement of immunizing antigens to produce functional blocking antibodies against the AniA nitrite reductase of Neisseria gonorrhoeae. PLOS One. 2017; 12: e0182555. PubMed Abstract | Publisher Full Text | Free Full Text
125. Shewell LK, Ku SC, Schulz BL, et al:: Recombinant truncated AniA of pathogenic Neisseria elicits a non-native immune response and functional blocking antibodies. Biochem Biophys Res Commun. 2013; 431(2): 215-20. PubMed Abstract | Publisher Full Text | Free Full Text

126. Tommassen J, Arenas J: Biological Functions of the Secretome of Neisseria meningitidis. Front Cell Infect Microbiol. 2017; 7: 256. PubMed Abstract | Publisher Full Text | Free Full Text

127. Cornelissen CN, Hollander A: TonB-Dependent Transporters Expressed by Neisseria gonorrhoeae. Front Microbiol. 2011; 2: 117. PubMed Abstract | Publisher Full Text | Free Full Text

128. Semchenko EA, Day CJ, Seib KL: MetQ of Neisseria gonorrhoeae Is a SurfaceExpressed Antigen That Elicits Bactericidal and Functional Blocking Antibodies. Infect Immun. 2017; 85(2): e00898-16. PubMed Abstract | Publisher Full Text | Free Full Text

129. Sikora AE, Gomez C, Le Van A, et al:: A novel gonorrhea vaccine composed of MetQ lipoprotein formulated with $\mathrm{CpG}$ shortens experimental murine infection. Vaccine. 2020; 38(51): 8175-84 PubMed Abstract | Publisher Full Text | Free Full Text

130. Wang S, Xue J, Lu P, et al.: Gonococcal MtrE and its surface-expressed Loop 2 are immunogenic and elicit bactericidal antibodies. $J$ Infect. 2018; 77(3): 191-204. PubMed Abstract | Publisher Full Text

131. Lewis LA, Rice PA, Ram S: Role of Gonococcal Neisserial Surface Protein A (NspA) in Serum Resistance and Comparison of Its Factor H Binding Properties with Those of Its Meningococcal Counterpart. Infect Immun. 2019; 87(2): e00658-18. PubMed Abstract | Publisher Full Text | Free Full Text

132. Moran EE, Burden R, Labrie JE, et al.: Analysis of the bactericidal response to an experimental Neisseria meningitidis vesicle vaccine. Clin Vaccine Immunol. 2012; 19(15): 659-65. PubMed Abstract | Publisher Full Text | Free Full Text

133. van der Ley $\mathrm{P}$, Heckels JE, Virji M, et al.: Topology of outer membrane porins in pathogenic Neisseria spp. Infect Immun. 1991; 59(9): 2963-71. PubMed Abstract | Publisher Full Text | Free Full Text

134. Edwards JL, Entz DD, Apicella MA: Gonococcal phospholipase d modulates the expression and function of complement receptor 3 in primary cervical epithelial cells. Infect Immun. 2003; 71(11): 6381-91. PubMed Abstract | Publisher Full Text | Free Full Text

135. Edwards JL, Jennings MP, Apicella MA, et al:: Is gonococcal disease preventable? The importance of understanding immunity and pathogenesis in vaccine development. Crit Rev Microbiol. 2016; 42(6): 928-41. PubMed Abstract | Publisher Full Text | Free Full Text

136. Zielke RA, Le Van A, Baarda BI, et al:: SliC is a surface-displayed lipoprotein that is required for the anti-lysozyme strategy during Neisseria gonorrhoeae infection. PLOS Pathog. 2018; 14(7): e1007081.

PubMed Abstract | Publisher Full Text | Free Full Text

137. Price GA, Masri HP, Hollander AM, et al:: Gonococcal transferrin binding protein chimeras induce bactericidal and growth inhibitory antibodies in mice. Vaccine. 2007; 25(41): 7247-60

PubMed Abstract | Publisher Full Text | Free Full Text

138. Hubert K, Devos N, Mordhorst I, et al.: ZnuD, a potential candidate for a simple and universal Neisseria meningitidis vaccine. Infect Immun. 2013; 81(6): 1915-27 PubMed Abstract | Publisher Full Text | Free Full Text

139. Stork M, Bos MP, Jongerius I, et al.: An outer membrane receptor of Neisseria meningitidis involved in zinc acquisition with vaccine potential. PLOS Pathog 2010; 6(7): e1000969. PubMed Abstract | Publisher Full Text | Free Full Text

140. Goytia M, Hawel L 3rd, Dhulipala VL, et al:: Characterization of a spermine/ spermidine transport system reveals a novel DNA sequence duplication in Neisseria gonorrhoeae. FEMS Microbiol Lett. 2015; 362(16): fnv125. PubMed Abstract | Publisher Full Text | Free Full Text

141. Gulati S, Zheng B, Reed GW, et al:: Immunization against a saccharide epitope accelerates clearance of experimental gonococcal infection. PLOS Pathog. 2013; 9(8): e 1003559. PubMed Abstract | Publisher Full Text | Free Full Text

142. Gulati S, McQuillen DP, Mandrell RE, et al:: Immunogenicity of Neisseria gonorrhoeae lipooligosaccharide epitope $2 \mathrm{C7}$, widely expressed in vivo with no immunochemical similarity to human glycosphingolipids. J Infect Dis. 1996; 174(6): 1223-37. PubMed Abstract | Publisher Full Text

143. Gulati S, Shaughnessy J, Ram S, et al.: Targeting Lipooligosaccharide (LOS) for a Gonococcal Vaccine. Front Immunol. 2019; 10: 321. PubMed Abstract | Publisher Full Text | Free Full Text | Faculty Opinions Recommendation

144. Seib $K L$, Haag $A F$, Oriente $F$, et al:: The meningococcal vaccine antigen GNA2091 is an analogue of YraP and plays key roles in outer membrane stability and virulence. FASEB J. 2019; 33(11): 12324-35. PubMed Abstract | Publisher Full Text

145. Soto SM: Human migration and infectious diseases. Clin Microbiol Infect. 2009; 15 Suppl 1(Suppl 1): 26-8. PubMed Abstract | Publisher Full Text | Free Full Text 